\title{
SECURING THEIR FUTURE? ENTRY AND SURVIVAL IN THE INFORMATION SECURITY INDUSTRY
}

\author{
Ashish Arora \\ Anand Nandkumar \\ Working Paper 13634 \\ http://www.nber.org/papers/w13634
NATIONAL BUREAU OF ECONOMIC RESEARCH
1050 Massachusetts Avenue
Cambridge, MA 02138
November 2007

The views expressed herein are those of the author(s) and do not necessarily reflect the views of the National Bureau of Economic Research.

(C) 2007 by Ashish Arora and Anand Nandkumar. All rights reserved. Short sections of text, not to exceed two paragraphs, may be quoted without explicit permission provided that full credit, including (c) notice, is given to the source. 
Securing Their Future? Entry And Survival In The Information Security Industry Ashish Arora and Anand Nandkumar

NBER Working Paper No. 13634

November 2007

JEL No. L24,L25,L26

\begin{abstract}
$\underline{\text { ABSTRACT }}$
In this paper we study how the existence of a functioning market for technology differentially conditions the entry strategy and survival of different types of entrants, and the role of scale, marketing ability and technical assets. Markets for technology facilitate entry of firms that lack proprietary technology and increase vertical specialization. However, they also increase the relative advantage of downstream capabilities, which is reflected in the relatively improved performance of incumbent Information and Communication Technologies (ICT) firms compared to startups. We find that diversifying entrants perform better relative to startups. Contrary to earlier studies, we find that spin-offs do not perform any better than other startups. Moreover, firms founded by serious hobbyists and tinkerers, whom we call hackers, perform markedly better than other startups. These findings reflect the non-manufacturing setting of this study, as well as the distinctive nature of software technology.
\end{abstract}

\author{
Ashish Arora \\ Heinz School, Carnegie Mellon University \\ 2508 Hamburgh Hall \\ 5000 Forbes Avenue \\ Pittsburgh PA 15213 \\ ashish@andrew.cmu.edu \\ Anand Nandkumar \\ Heinz School, \\ Carnegie Mellon University \\ 2501 Hamburgh Hall \\ 5000 Forbes Avenue \\ Pittsburgh PA 15213 \\ anandn@andrew.cmu.edu
}




\section{Introduction:}

Studies of industry evolution conclude that established firms tend to outperform startups (Dunne et al., 1988; Mitchell, 1991; Klepper and Simons, 2000a; Klepper, 2002). A variety of possible sources of advantage have been identified. Established firms are larger, endowed with complementary assets like distribution and marketing networks, better management capabilities, and even perhaps superior technology. The relative importance of these factors in the advantage that established firms enjoy over startups remains unclear. The literature also concludes that the pre-entry experience of entrants is very important, so that spinoffs from existing firms or startups from related industries outperform others. Once again, the precise nature of the relevant prior experience is less clear (Chatterji, 2006).

Existing literature implicitly focuses on firms that rely upon internally generated technologies. We explicitly consider how markets for technology condition the entry strategy and the subsequent performance of entrepreneurs, and changes the relative value of different types of firm competencies. ${ }^{1}$ At the very least, the existence of technology suppliers expands the strategy space of the entrepreneur. As Gambardella and Giarratana (2006) point out, technology holders may choose to license technology to others. Other entrants, especially incumbent ICT firms diversifying into the Information Security Market (ISM) may find it more profitable to acquire external technology than to develop the technology by themselves. (Arora, Fosfuri and Gambardella, 2001, Gans, Hsu and Stern ,2002).

In addition, markets for technology may also condition the subsequent fate of entrants. Lowered entry barriers may mean more competition and greater likelihood of exit. More interestingly, the relative performance of different types of entrants may also be affected,

\footnotetext{
${ }^{1}$ Gambardella and Giarratana (2006) analyze the factors that condition how encryption technology holders choose between licensing technology rather than offering products for sale.
} 
changing the relative importance of production and marketing ability compared to technical ability.

To answer these questions we develop a novel dataset of entrants in the ISM. Before the internet, computer attacks, with the exception of viruses, were largely restricted to large computer networks typically owned by the government. The large scale adoption of the internet in the mid 1990's meant that a growing amount of commercially valuable data had to be protected against attackers, accidental loss, and prying eyes. The growth of digital products (including songs and videos) required means of controlling the access and use of those products. Further, online commerce required authenticating participants, secure communications and controlling access. More recently, users have to be protected against spam and "phishing" attacks, which induce unwary users to part with confidential information. Thus, the ISM consists of several submarkets that emerged at different points in time.

Given the general-purpose nature of information technology, entrants into the ISM are diverse: software, hardware or telecommunication equipment producers, startups with founders from these same IT industries, as well as from industries such as defense and financial services have all entered the ISM. However, what perhaps distinguishes the ISM is the rarity of spinoffs and perhaps also the number of pioneering startups founded by very skilled hobbyists or tinkerers, whom we shall call "hackers".

This paper is organized as follows: section 2 provides a brief background on information security technologies. Section 3 reviews literature and provides a theory that guides our empirical analysis in section 5. Section 4 provides a description of the data. In section 6 we conclude with a summary of our key findings of this work.

\footnotetext{
${ }^{2}$ Hackers lack advanced degrees in computer sciences, nor do they hold important positions in established ICT firms at the time of founding. Yet, in ISM, they are among the pioneers and, more interestingly, the source of many of the current market leaders.
} 


\section{Information security market:}

Four major types of technologies are involved in securing information and computer networks: (i) Encryption, to disguise data and preserve confidentiality of transactions (ii) Packet inspection and filtering, based on pattern matching (for firewalls, anti-virus and intrusion detection) (iii) Image matching, to identify end users to systems based on their physical attributes such as fingerprints, retina and (iv) "Single sign on" technology to enable users to be authenticated to multiple systems just using own common password.

(i) Encryption: Encryption relies heavily upon the science of cryptography. Before the internet, encryption was used to protect communication, such as communication between ATM terminals and central banking servers. Innovation in computer networking accentuated the need for more sophisticated methods of encryption on a public computer network, resulting in the invention of public key encryption in $1976 .^{3}$ Encryption uses encryption keys generated by multiplying two large random prime numbers. Decryption, on the other hand, involves factoring this large number to figure to discover the prime number that was originally used to encrypt the data. Public key cryptography was first applied for encrypting email.

Internet and e-commerce, and the increased sophistication of attacks, increased the need for encryption technology. This in turn, meant larger keys had to be used to encrypt data which, required greater processing power. Also, the need for encryption solutions on small devices such as smart cards, cell phones and PDAs (where limited amount of data, including encryption strings, can be stored) required more efficient methods of encryption. Certicom, another important player in the encryption market, successfully invented a more efficient algorithm for public key cryptography called elliptic curve cryptography in 1997. At present RSA and

\footnotetext{
${ }^{3}$ In 1976, a public key technology called the Diffie-Hellman algorithm was invented at Stanford in 1976. RSA, another key algorithm for public key cryptography was invented at MIT in 1977.
} 
elliptical curve algorithms invented by Certicom are the two most widely used encryption methods to protect data.

(ii) Pattern Matching and filtering: Pattern matching technology builds on routing technologies that direct internet communications. These products scan network traffic and make decisions based on parameters such as the source and destination of internet traffic. The advent of the internet required more sophisticated filtering and checks. The most important filtering technology is the stateful inspection technology, which, is a method to keep track of previous communication between two networked computers. This technology was invented by, Checkpoint Technologies, a startup established in Israel, in 1996.

(iii) Image matching: Image matching or biometric technologies are used to verify or recognize the identity of a person based on a physical characteristic like fingerprints or retina patterns. There are three basic methods (1) a mechanism to scan and capture an image; (2) compression, processing and comparison of the image to a database of stored images; and (3) interface with applications systems ${ }^{4}$. Large hardware producers like Hughes, IBM, Burroughs and Harris Corporation, and defense contractors were among the early participants in this technology, as biometric technologies were used principally by government agencies and financial firms prior to 1997. With increased use of mobile computing, the demand for biometric technologies has grown rapidly.

(iv) Single sign on: Single sign on technologies are algorithms that enable users to use one password and log on to multiple computer systems. For example, Kerberos invented at MIT, is widely used in universities to authenticate students and staff to multiple systems with just one

\footnotetext{
${ }^{4}$ Source http://www.afmc.wpafb.af.mil/organizations/HQ-AFMC/LG/LSO/LOA/bio.htm. Retrieved February 4th, 2007.
} 
password. Since one of the selling points of e-commerce was the ability to conduct transactions between two unknown parties, verifying identify instantaneously became another critical function of this technology.

(v) Services: In addition consulting firms advise enterprises about compliance with regulatory mandates, including HIPPA, Sarbanes Oxley, Basle II, Gramm-Leachman-Bailey, and various DoD mandates, such as Phipps and Common Criterion.

ISM products typically combine one or more of ISM technologies (see table 1 below) ${ }^{5}$ as a product to cater to the needs of users. For instance, a Virtual Private Network (VPN) product uses encryption to enable organizations and desktop users to securely communicate using the internet. Authentication products use encryption (sometimes combined with pattern or image matching) to regulate user access to the network.

Entrants into the ISM can either be in the product market (also called "downstream"), in the licensing market ("upstream"), or both (also called "both"). In our data, there are few upstream entrants, all of them licensing encryption technology. RSA and Certicom are two of the most successful firms that license encryption technology mainly to network security and authentication product vendors. ${ }^{6}$ Other technologies such as image matching, pattern matching and single sign on are sold by vendors that also sell products incorporating the technology. For instance, Symantec not only sells an antivirus product, but they also license pattern-matching technology. Similarly, Checkpoint not only manufactures and sells firewall known as Firewall-1, but it also licenses pattern matching technology to other firewall producers.

\footnotetext{
${ }^{5}$ In our empirical analysis, we shall frequently group downstream segments into two - those based on encryption technologies, and those based on other technologies. However, the results are not affected by treating firewalls, antivirus, spam, hardware and consulting as distinct from each other and from network security, authentication and encryption products. Neither are our results affecting by treating only network security and encryption products as encryption based and leaving out authentication (which also relies upon single sign-on technology, and perhaps also image matching.)

${ }^{6}$ RSA after its merger with Security Dynamics in the late 1990's entered product markets.
} 
Table 1 ISM technology and product map

\begin{tabular}{ccccc}
\hline & Encryption & Image-matching & $\begin{array}{c}\text { Pattern } \\
\text { matching }\end{array}$ & Single Sign-On \\
\hline Firewall & & & $\mathrm{X}$ & \\
Antivirus & $\mathrm{X}$ & $\mathrm{X}$ & $\mathrm{X}$ & $\mathrm{X}$ \\
Authentication & $\mathrm{X}$ & & \\
Spam & $\mathrm{X}$ & $\mathrm{X}$ & \\
Network (VPN) & & & \\
Encryption & & & \\
Hardware & & & \\
Consulting & & & \\
\hline
\end{tabular}

\section{Previous literature and Theory}

Our work draws from two streams of literature: strategy literature and entrepreneurship literature.

Evolutionary economists conjecture that the historical antecedents of entrepreneurs, especially pre-entry experiences not only condition entry strategies, but also subsequent performance. These capabilities include technology, production expertise and facilities, brand name and reputation, human assets, established marketing channels, that are typically rare, valuable, imperfectly mobile (Barney, 1991; Markides and Williamson, 1996) and typically must be accumulated internally (Dierickx and Kool, 1989). In fact, many empirical researchers take the view that one reason that firm size is positively correlated with survival is because firm size captures the effects of learning and accumulation of relevant competitive assets post entry (Geroski, 1995), a fact that is also true of small firms (See Audretsch and Mahmood, 1995 or Dunne et al 1989 for example).

Diversifying entrants tend to enter industries whose resource requirements are similar to their own. For instance, in the television industry, many of the early entrants were radio producers (Klepper and Simons, 2000a). Similarly in the automobile industry, entrepreneurs with experience in manufacturing carriages and bicycles not only entered early relative to other entrants but also survived longer (Klepper, 2002). Many studies of large manufacturing firms 
conclude that a greater fit between the resource requirements of the new industry and that of the potential entrant increases the likelihood of entry (Chatterjee and Wernerfelt, 1991; Chang, 1997; Merino and Rodriguez, 1997; Silverman, 1999). The fit could be based on technology or marketing. For instance, in the television industry, 14 out the 16 top radio producers in 1940 diversified into the television industry (Klepper and Simmons, 2000). Similarly, in the automobile industry about $47 \%$ of the entrants diversified from related industries that included bicycle, carriage or engine manufacturing (Carroll et al, 1996).

Although diversifiers are the most important type of entrant, startups, including firms spun out of existing producers (spinoffs), typically constitute the majority of entrants (Dunne, Roberts, and Samuelson, 1988). Spinoffs may occur due to disagreements between the manager and employee (Klepper and Thompson, 2005) typically about how best to exploit new idea. Spinoffs could also occur when property rights are non-existent or weak or when the employee owns the rights to an invention (Anton and Yao, 1995). When the external environment is conducive to startups parent firms might actively encourage exploration of new ideas and exploit it in house (Hellmann, 2006). Unlike other industries studied by scholars, there are far fewer spinoffs in ISM compared to other industry settings, perhaps reflecting the relative youth of ISM.

Lead users, with extensive knowledge of consumer preferences, were also sources of entry into even manufacturing centric industries such as typesetting (Tripsas, 2001). Many industries also witness entry by entrepreneurs with very specific technical knowledge. In the medical devices industry, for instance, clinical doctors often identify opportunities that lead to new types of devices (Chatterji, 2006).

Pre-entry experience may also be critical for subsequent performance (Helfat and Lieberman, 2002). For instance, Thompson (2002), using data on the ship building industry, 
found that pre-entry experience of entrants has a strong and long- lasting positive effect on firm survival that went beyond scale economies and learning subsequent to entry. Klepper (2002) and Carroll et al, (1996) found similar patterns for automobiles, Mitchell (1989) for medical imaging, and Klepper and Simons, (2000a) for televisions.

However there is less consensus on which types of pre-experience is more valuable, perhaps because the nature of industry dictates which experiences are more valuable than others. For instance, in televisions, the ability to conduct $R \& D$ was a distinct source of advantage to the radio manufactures that not only enabled them to enter early but also survive longer (Klepper and Simons, 2000a). In the medical imaging industry, the advantage to diversifying entrants was due to their superiority in sales and distribution (Mitchell, 1989).

Similarly, while prior research has shown that pre-entry experiences of founders influence subsequent performance of startups, the type of experience that conditions subsequent performance varies with the industry that is investigated. Startups from related parents were more likely to succeed in automobiles (Klepper, 2002) and shipbuilding industries (Thompson, 2002) by virtue of their experience in fabrication. In lasers, spinoffs succeeded based on their technical expertise gained while working for the parent (Klepper and Sleeper, 2005). In other industries, spinoff success was based on non-technical learning, such as knowledge of FDA approval process in medical devices (Chatterji, 2006). In our empirical analysis we compare the subsequent performances of different types of entrants and also the sources of such performance advantages.

Prior work by strategy scholars indicates that not only do markets for technology exist within ISM, but more importantly they also condition firm strategy (Arora, Fosfuri and Gambardella, 2001; Gans, Hsu and Stern, 2002). Encryption technologies are patent intensive 
relative to other ISM technologies and are extensively licensed (Giarratana, 2004). Gambardella and Giarratana (2007) analyze how markets for technology affect the choice between licensing or developing a product.

We explore how the presence of markets for technology influences entry strategy and subsequent performance of firms in the ISM. Also we explore which competencies are relatively more important than others both in the presence and absence of markets for technology.

\section{Theory}

We motivate our empirical analysis with a stylized model to derive predictions to guide our empirical analysis. We make several simplifying assumptions, particularly about inter-firm heterogeneity and the sources of pre-entry uncertainty to develop a tractable model where both the product market and the market for technology are in equilibrium. An important simplification is that we do not analyze industry dynamics. Rather, all firms enter at the same time. At the time of entry, firms are uncertain of their profitability in the product market. Following entry, this uncertainty is resolved and some firms exit. The market clearing prices in the product and technology markets reflect this entry and exit.

Notation and assumptions:

We assume that firms entering the product market require technology and the ability to produce and market the product(s). A proportion of the potential entrants, $\lambda$, are endowed with a technology, while others have to acquire it from a technology supplier. Firms endowed with technology decide whether to enter only the product market (downstream), only the technology market (upstream) or both ("both" segment).

Firms differ in how efficiently they can produce and sell an ISM product. In general, efficiency is multifaceted. However, we assume that more efficient firms produce and sell a 
higher quantity denoted by $q$. Thus $q$ is a summary measure of the differences in efficiency (as well as scale), and is distributed in the population with distribution function $\mathrm{F}(\mathrm{q})$. The cost function for firms in the product market is $\mathrm{cq}+\theta$, where $\mathrm{c}$ is the marginal cost and $\theta$ is a fixed cost. ${ }^{7}$ The actual fixed cost of each firm is $\theta+\varepsilon$, where $\varepsilon$ is a mean zero iid random variable. At the time of entry, firms do not observe $\varepsilon$, and thus are uncertain about their true profitability in the product market. However after entry, this uncertainty is resolved. This is a simple modeling device to produce exit from the product market, and is a variant of the approach used in Jovanovic (1982). Ignoring product heterogeneity, we assume that the demand for the product $\mathrm{D}(\mathrm{p})$, is decreasing in $p$, the product price.

Modeling the technology market is more challenging. We adopt a reduced form approach. Each licensor earns license revenues of $L$. Licensees buy technology at a price of $\tau$. We do not model how $\tau$ is determined. Instead, $\tau$ is simply assumed to be a decreasing function of the total number of licensors, M. We further assume that there are diseconomies of scope when firms enter "both" segment, denoted by $\gamma$ per unit of output produced and sold by the firm. This cost denotes the rent dissipation effect due to erosion of profits due to another firm (licensees) competing in the product market (Arora and Fosfuri, 2003). All licensors incur a sunk entry cost of $E$. Finally, we assume that there are some technology suppliers that are pure licensors, whose number, $\mathrm{b}$, is exogenous to the model. These can be thought of representing inventors and university researchers that have developed technology that they offer for license.

Underlying this reduced form we have in mind a situation where technologies offered for license are symmetric but each potential buyer has some idiosyncratic preferences, reflecting its own market niche. Licensors compete for each potential buyer in a Vickery type second price

\footnotetext{
${ }^{7}$ Even for digital products such as information security products, there are incremental costs of reaching and servicing additional buyers, customizing products for their needs and so on.
} 
auction. The winning licensor is paid the incremental value it offers over the next best bidder. This would lead to the familiar outcome where the market is divided equally among the suppliers and all suppliers charge the same non-zero price, which decreases with the total number of suppliers, but does not depend upon the number of buyers.

Profits

Profits in the downstream segment (product market) are given by $\Pi_{\mathrm{D}}=(p-c) q-\theta$. The profits of firms that both supply technology and produce is given by $\Pi_{\mathrm{B}}=(p-c-\gamma) q-\theta+L-E$. The profits of a firm that only supplies technology is given by $\Pi_{\mathrm{L}}=L-E$.

Entry

Firms not endowed with technology enter only expected profits (p-c)q - $\theta$ are greater than $\tau$, the cost of licensing technology. The probability of entry is given by $F\left(\frac{\theta+\tau}{(p-c) q}\right)$. Figure 1 plots the profit of different types of entrants as a function of $q$. Firms endowed with technology do not produce but instead only license when $\frac{\theta}{p-c-\gamma}>\mathrm{q}$. When $\frac{\theta}{p-c-\gamma}<\mathrm{q}<\frac{L-E}{\gamma}$, they both sell products and license, and exclusively sell products when $\mathrm{q}>\frac{L-E}{\gamma}$. Firms not endowed with technology enter when $\mathrm{q}>\frac{\theta+\tau}{p-c}$. The share of entrants with technology that enter "both" is given by $\lambda\left(F\left(\frac{L-E}{\gamma}\right)-F\left(\frac{\theta}{p-c-\gamma}\right)\right)$. Similarly, the share of entrants with technology that exclusively sell is just $\lambda\left(1-F\left(\frac{L-E}{\gamma}\right)\right)$, and the share that only license is $\lambda F\left(\frac{\theta}{p-c-\gamma}\right)$.

Exit: Post entry, firms realize an operating cost of $\theta+\varepsilon$, where $\varepsilon$ denotes iid shocks that is mean zero, distributed $\mathrm{H}($.$) . The probability of exit for firms that enter downstream is given by the$ 
probability that $(p-c) q-(\theta+\varepsilon)<0$, which is just $1-\mathrm{H}[(p-c) q-\theta]$. Firms that entered the "both" segment have a higher probability of exit given by $1-\mathrm{H}[(p-c-\gamma) q-\theta]$. Note that we implicitly assume that firms that are exclusive technology suppliers do not exit the ISM. Our data largely supports this assumption. Of a total of 17 pure technology suppliers, only 1 exited. $^{8}$

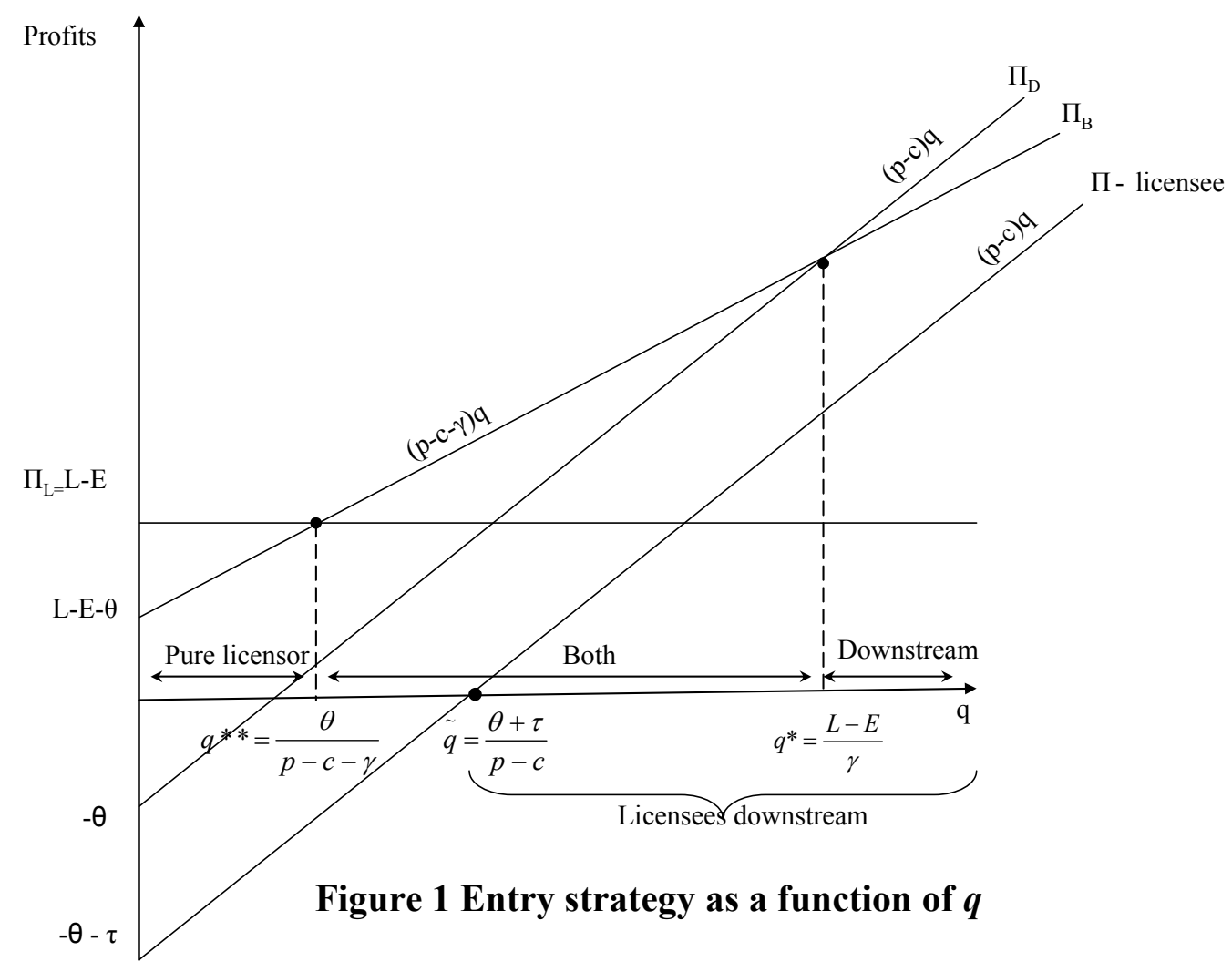

\section{$\underline{\text { Market Equilibrium }}$}

Market equilibrium involves two interrelated markets: The product market and the technology market. Equilibrium in product market implies that the quantity supplied by producers must equal the quantity demanded. The quantity supplied in the product market is the total quantity supplied by the survivors in the product market. This condition is thus given by

\footnotetext{
${ }^{8}$ The assumption of no exit from the licensing market is made mostly for modeling convenience. We conjecture that allowing exit from the licensing market will not qualitatively affect our results. It does, however, complicate exit probabilities for firms in the "both" segment.
} 


$$
D(p)=T\left\{\begin{array}{l}
\frac{\lambda}{1-F\left(\frac{L-E}{\gamma}\right)} \int_{\frac{L-E}{\gamma}}^{\infty} q H((p-c) q-\theta) d F+\frac{\lambda}{F\left(\frac{L-E}{\gamma}\right)-F\left(\frac{\theta}{p-c-\gamma}\right)} \int_{\frac{\theta}{p-c-\gamma}}^{\frac{L-E}{\gamma}} q H((p-c-\gamma) q-\theta) d F \\
+\frac{1-\lambda}{1-F\left(\frac{\theta+\tau}{p-c}\right)} \int_{\frac{\theta+\tau}{p-c}}^{\infty} q H((p-c) q-\theta) d F
\end{array}\right\}
$$

In the technology market, market clearing is more subtle. Any given licensor can sell as many licenses as required. The equilibrium condition is that the total license revenues (of all technology suppliers), should equal the total licensing payments. The former is LM, and the latter is equal to the number of licensees multiplied by the license price $\tau$.

$$
L M=(1-\lambda) \tau\left[1-F\left(\frac{\theta+\tau}{p-c}\right)\right] T
$$

where $\mathrm{M}$ is given by

$$
M=T \lambda F\left(\frac{L-E}{\gamma}\right)+b
$$

To get some intuition into these market clearing conditions, figure 2 shows how $\mathrm{M}$ and $p$ are related for each market clearing condition. The PP curve represents equilibrium in the product market, and TT curve represents equilibrium in the technology market. While PP curve is downward sloping, the TT curve is upward sloping (all proofs are contained in the appendix). The intersection represents market equilibrium, with $p^{*}$ and $\mathrm{M}^{*}$ as the equilibrium price and technology suppliers. Figure 2 shows that an increase in $\mathrm{b}$ increases $\mathrm{M}^{*}$ and reduces $p^{*}$.

The model has a number of testable predictions. The formal statements and proofs are all contained in the appendix. Here we state the results verbally. As shown in figure 1, it predicts that larger firms will, if they enter, produce rather than license, even if these firms have proprietary technology. Licensing to others is not attractive because such licensing creates competition in the product market and dissipates rents. In our empirical analysis, we measure 
the entrant size. However, we have a number of other measures that plausibly proxy for different dimensions of efficiency such as the number of trademarks, as well as whether the firm is an existing firm entering the ISM market.

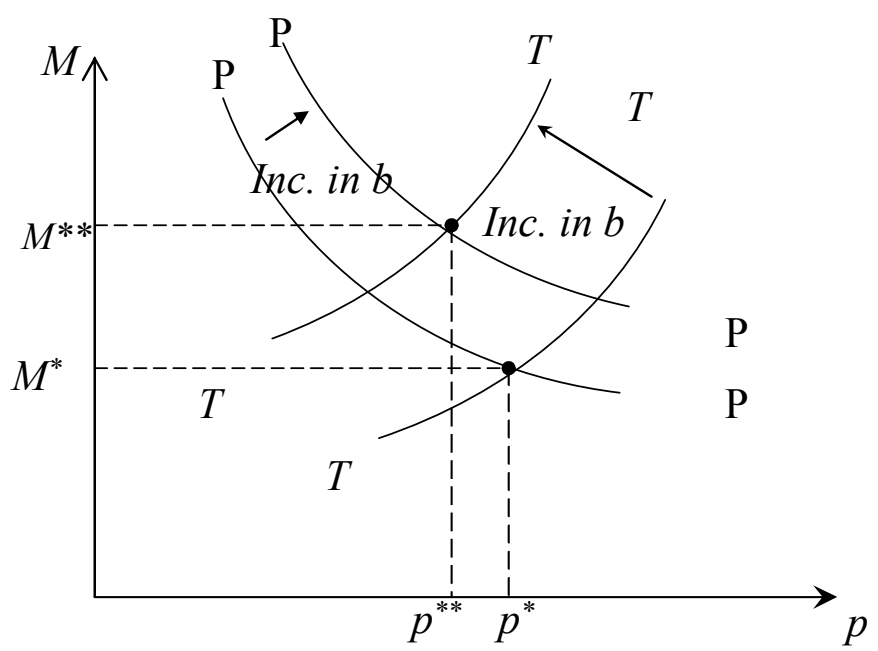

Figure 2 Equilibrium

Result 1: Increases in firm scale increases the proportion of downstream entry. More generally, increases in firm efficiency increase the proportion of downstream entry.

The model implies that an increase in $b$ increases the probability of entry into the downstream segment by firms endowed with technology, as well as those that are not. An increase in $b$ has two effects. It decreases the license price, $\tau$, and reduces $p$, the product price. For producers endowed with technology, an increase in b makes licensing less attractive: the firm indifferent between downstream and both now prefers downstream. For firms without technology, the net effect is to encourage entry, which by definition is downstream.

Result 2: An increase in competition in the market for technology will increase the probability of downstream entry. 
If competition in the market for technology lowers entry barriers into the product market, this also implies more intense competition in the product market. More intense competition should hurt the average performance, increasing the likelihood of exit or slowing growth rates. When more firms enter due to lower entry barriers, prices fall, resulting in higher exits rates on average. Thus, a reduction of entry barriers increases the probability of exit by increasing the overall number of firms and lowering prices. In our model, entrants account for this higher probability of exit in their entry decisions. However, since there is no sunk entry cost, this does not affect their entry decisions. A modest entry cost will not change the result since ultimately the higher exit is due to lower prices, which will only happen if there is net entry.

Result 3: Increased competition in market for technology will increase average exit rates.

Since the probability of exit is decreasing in $q$, firms with higher values of $q$ are less likely to exit, all else equal. More generally, efficient producers and marketers of products are, all else constant, less likely to exit the ISM as well.

Result 4: Increases in firm scale reduce exit. More efficient firms have a lower probability of exit relative to less efficient firms.

The final result concerns how increases in the competition in the market for technology differentially affect firms with different scales of operation. In our model, there are two offsetting forces. Firms with larger q are more likely to suffer greater losses from a drop in price. However, more efficient and larger firms are also more likely to survive cost shocks relative to less efficient firms. Which of these effects dominates depends upon the distribution of the cost shocks. We show that under some restrictions, which are, for instance satisfied by the exponential family (including the normal), the latter effect outweighs the former, so that an increase in competition in the market for technology increases exit for smaller firms by more, 
than for larger firms. Although this result is a limited one, we believe it reflects a broader intuition, namely that as technology becomes cheaper, the sources of differentiation shift towards other sorts of assets, including production and marketing. In our model, we do not allow for differential access to technology, or for a competitive advantage to firms with proprietary technology. We conjecture that in a model with these features such a result would hold a fortiori.

Result 5: Increased competition in market for technology increases average exit rate by more for smaller firms than for larger firms.

\section{Data:}

Our sample consists of 343 security firms, followed from the time of entry until 2004 or their exit, whichever is earlier. From the Corptech directory, we obtained names of all firms that entered ISM between 1989 and 2004. This dataset was manually augmented with information on submarkets of entry using Internet archives (www.archive.org), an internet web site that maintains historical archives of many web sites.

Firms in our sample exited due to two reasons: non viability of the business (death) or acquisition by another firm (merger) (identified using Lexis-Nexus mergers and acquisitions database). These were coded separately in the dataset. We distinguish between successful acquisitions (based on reported transaction values) and distress acquisitions. As we will explain later, while comparing performance of firms in the ISM we treat the successful acquisitions as censored observations and distress acquisitions as death.

In addition, we recorded the sources of entry by tracking information about the founders (for up to 4 founders) of security firms. Such data was collected from a variety of publicly available data sources on the internet such as ZoomInfo (www.zoominfo.com), LinkedIn 
(www.linkedIn.com), Google Archives (www.archives.google.com), Internet Archive (www.archive.org) and, EDGAR database.

We classified startups into one or more of the following categories based on the immediate prior experience of founders: spin-offs (firms founded by employees of an ISM firm), related startups (startups founded by employees of computer hardware, software or telecommunication firms), unrelated startups (founders from defense, finance, aerospace and automobile industries), university founders, hackers ${ }^{9}$ and IT consultants. ${ }^{10}$ In our empirical analysis, we frequently club unrelated startups with hackers and universities (referred to as "other" category henceforth) thereby, focusing the analysis on diversifiers, related startups spinoffs and unrelated startups.

For all sample firms, we also collected the number of security related patents and all IT trademarks held by the firms at the time of entry into ISM from the U.S.PTO database. Security related patents are those that belong to the US patent technological classes 705 subclass $50-79$, 380 and 726 . We then weighted the patents using the number of forward citations to account for their relative value and importance of patents (Trajtenberg, 1990). For IT trademarks, we did keyword search on the U.S.PTO trademarks database (http://tess.uspto.gov) to gather the number of IT related trademarks held by the firm. ${ }^{11}$ We also collected data on licensing transactions from the Lexis-Nexus database. We were able to identify if firms entered the ISM by licensing a technology only in the case of 120 firms. We use data on licensing transactions only in auxiliary regressions to test the robustness of our main results.

\footnotetext{
${ }^{9}$ Hackers are defined as those that (a) do not have a CS or EE degree, (b) do not have high level experience in IT firms and (c) were self-employed prior to founding the firm.

${ }^{10}$ IT consultants are those that (a) have a CS or EE degree and (b) were self employed prior to founding the firm.

${ }^{11}$ We used the following search query on the trademark database. Trademark description includes ("computer") OR ("hardware") OR ("pixel") OR ("telecom") OR ("telecommunications") OR ("software") OR ("Wireless") OR ("computing") OR ("database") OR ("data base ") OR ("pixels") OR ("computer program") OR ("Network") OR ("LAN") OR ("Networking") OR (" computer protocol ") OR (" Internet ").
} 
We also identified the submarket of entry for all the firms using internet resources as stated above. For each entrant we first determined the submarket of entry. We then identified if entrants were selling only technology in which case they were classified as being technology suppliers (or "upstream"). Firms that were selling only products were classified as "downstream" firms, while firms that sold both products and technology were classified as operating in "both" markets. In the data set there are 17 technology suppliers that entered the ISM.

We also recorded the size of firms at the time of entry into the ISM. For startups this is the number of employees at the time of entry into the ISM. For diversifying entrants, we calculated size at the time of entry as follows: we first identified all the markets in which, diversifying entrants operated in at the time of entry; we then divided the total employees of the diversifier by the total number of markets that diversifiers operated in to get the size at the time of entry for diversifiers.

Table 2 Description of measures used

\begin{tabular}{|c|c|c|c|c|}
\hline Variable & Description & $\mathrm{N}$ & Mean & Std. Dev \\
\hline Downstream & $\begin{array}{l}\text { A dummy variable }=1 \text { if the entrant enters downstream } \\
\text { segment conditional upon entering ISM }\end{array}$ & 326 & 0.64 & 0.48 \\
\hline Log (1+security patents $)$ & $\begin{array}{l}\text { Log of } 1+\# \text { of weighted security patents held by a firm at } \\
\text { entry. This variable proxies technical capability }\end{array}$ & 326 & 0.37 & 0.91 \\
\hline $\log (1+$ IT trademarks $)$ & Log of IT trademarks held by firm at entry. & 326 & 0.94 & 1.01 \\
\hline Log (1+tech.suppliers) & $\begin{array}{l}\text { Log of } 1+\text { lagged technology suppliers. This is a proxy for } \\
\text { MFT }\end{array}$ & 326 & 2.52 & 0.51 \\
\hline $\log (1+$ Size $)$ & Log of $1+\#$ employees at entry. This is a proxy for scale & 300 & 3.89 & 1.60 \\
\hline Encryption market dummy & $\begin{array}{l}\text { Dummy variable for markets that use encryption } \\
\text { technology; covers NW security, authentication and } \\
\text { encryption product markets }\end{array}$ & 326 & 0.62 & 0.49 \\
\hline Licensee & $\begin{array}{l}\text { A dummy variable }=1 \text { if an entrant enters the ISM by } \\
\text { licensing technology }\end{array}$ & 120 & 0.71 & 0.46 \\
\hline Industry age & Age of the industry measured from 1970 & 326 & 8.87 & 5.68 \\
\hline ISM tenure & Calculated as current year - ISM entry year & 326 & 6.88 & 4.94 \\
\hline ICTdummy & $=1$ if the entrant is a diversifying ICT entrant & 326 & 0.17 & 0.38 \\
\hline
\end{tabular}




\begin{tabular}{lllcc}
\hline Unrelated startup dummy & $\begin{array}{l}=1 \text { if the entrant has a founding member from an unrelated } \\
\text { industry }\end{array}$ & 326 & 0.11 & 0.31 \\
Related startup dummy & Startup with a founder from an ICT firm & 326 & 0.48 & 0.5 \\
Competitors & Lagged number of producers (in the same submarket) & 326 & 22.80 & 18.30 \\
\hline
\end{tabular}

\section{Sources of firm formation and patterns of entry into ISM:}

The ISM has grown considerably over the past 15 years. The industry thusfar has not experienced a shakeout, as also confirmed by Giarratana (2004). In the 1980s, ISM mainly comprised of technologies rather than products used by a handful of enterprises and mainly by the defense industry. Entry (figure 1) shows two peaks - first around 1989 and the second one around 1995. The first peak was largely an after-effect of "moris" worm that sparked research in antivirus and network security technology. The advent of the internet increased entry, particularly by startups.

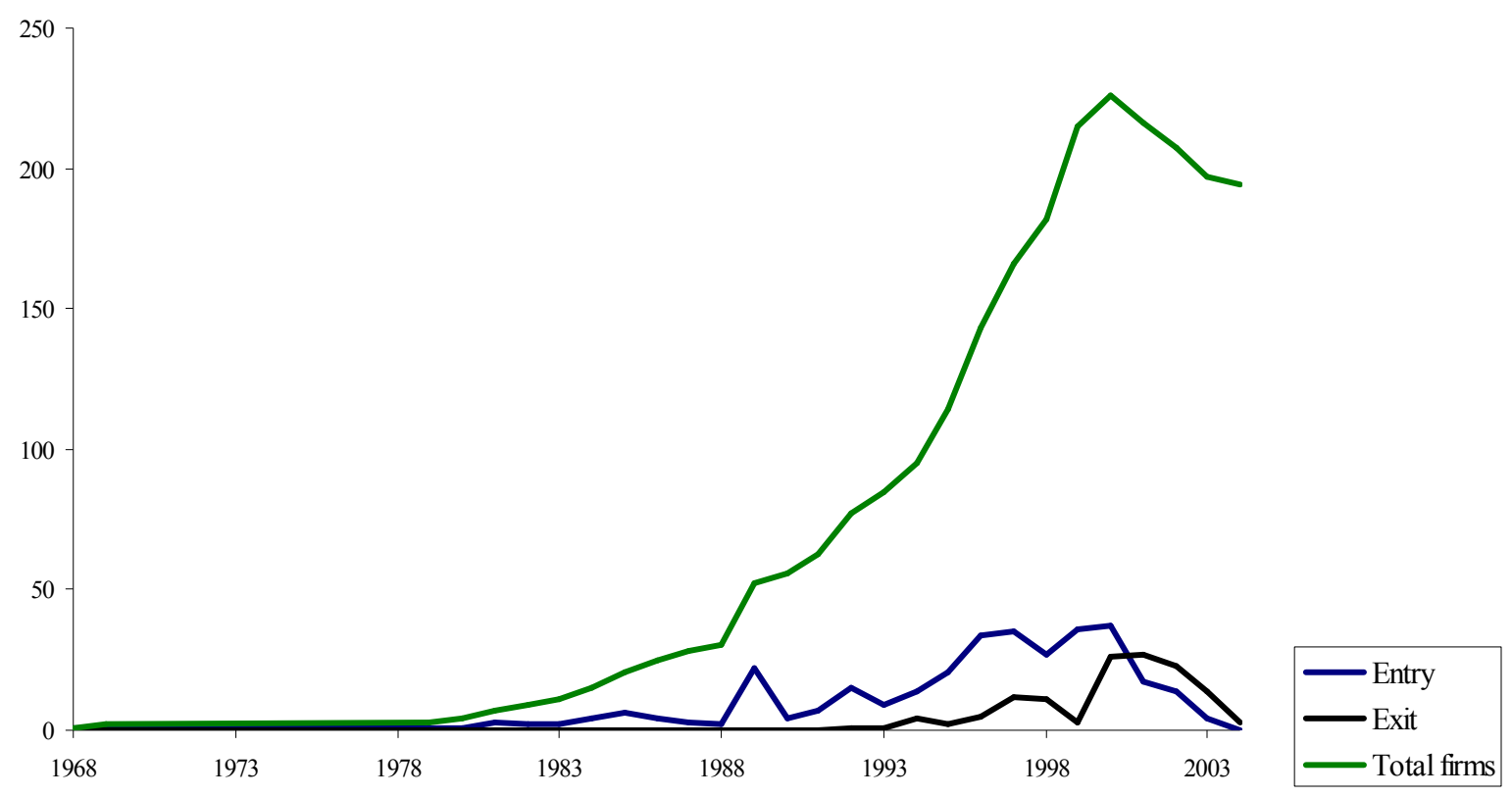

Figure 3 - Entry and exit into ISM

Entrants into the ISM have diverse origins (table 2). About $83 \%$ of the entrants into the ISM are startups, broadly similar to that of automobile industry. About $58 \%$ of the startups 
(about $48 \%$ of all entrants) have at least one founding member from a related industry such as computer hardware, software or telecommunications industry, a proportion, very similar to automobiles (where related startups were $47 \%$ of total entrants).

Table 3- Sources of entry in ISM

\begin{tabular}{lccccc}
\hline \multicolumn{1}{c}{ Entrant type } & ISM & Automobiles & TV industry & $\begin{array}{c}\text { Medical } \\
\text { devices }\end{array}$ & Laser \\
\hline Diversifiers & $17 \%$ & $17 \%^{\mathrm{a}} ; 35 \%{ }^{\mathrm{b}}$ & $30 \%^{\mathrm{e}}$ & - & - \\
Hackers & $10 \%$ & - & - & - & - \\
$\begin{array}{l}\text { Related startups } \\
\text { Unrelated }\end{array}$ & $45 \%$ & $47 \%^{\mathrm{a}}$ & & $34 \%{ }^{\mathrm{c}, \mathrm{y}}$ & $44 \%^{\mathrm{d}}$ \\
startups & $21 \%$ & $32 \%^{\mathrm{a}}$ & - & & \\
University & & & - & $29 \%{ }^{\mathrm{c}, \mathrm{z}}$ & $26 \%^{\mathrm{d}}$ \\
Spin-offs & $8 \%$ & - & & & $18 \%$ \\
\hline
\end{tabular}

Notes: The total proportion adds up to more than $100 \%$ because many firms have multiple founders. In our empirical analysis we club hackers and University professors with unrelated startups.

${ }^{\mathrm{a}}$ Carroll et al, 1996; ${ }^{\mathrm{b}}$ Klepper, 2002; ${ }^{\mathrm{c}}$ Chatterji, 2006; ${ }^{\mathrm{d}}$ Sleeper, 1996; ${ }^{\mathrm{e}}$ Klepper and Simons, 2000a

${ }^{\mathrm{z}}$ Compared with clinical doctors in medical devices industry.

${ }^{\mathrm{y}}$ Entrants from defense, financial services, insurance and aerospace compared with "outsider" + serial entrepreneurs in medical devices industry.

The ISM also witnessed entry by university based startups particularly in encryption, a pattern that was true of the laser industry (Sleeper, 1998) as well as of medical devices (Chatterji, 2006). However, the proportion of such entrants was significantly lower ( $8 \%$ in ISM vs. $26 \%$ in laser and 29\% in medical devices). Two interesting patterns emerge from comparing the entry patterns of ISM with that of other industries. First, many ISM firms (about 10\%) have been founded by hackers. (see table 3). Although such entry is virtually non-existent in other industries, it is not inconsistent with the view that in many industries lead users innovate, either to customize products or to fix problems in them. ${ }^{12}$ Hackers personify what von Hippel (2005) has dubbed the democratization of innovation, perhaps a throwback to the tinkerers and inventors of the 19th century. Second is the virtual absence of spin-offs in the ISM relative to other

\footnotetext{
${ }^{12}$ For, instance von Hippel, 2005 in his study found that nearly $50 \%$ of webmasters implemented custom extensions to the security module of Apache web server.
} 
industries. While in most manufacturing based industries, spin-offs constitute a big percentage of all startups, only $6 \%$ of all entrants were startups.

Overall, despite the pervasive nature of IT and non-manufacturing nature of the industry, the sources of entry in the ISM are surprisingly similar to other industries with two exceptions: first, is the possible exception of hackers and second is the virtual absence of spin-offs. Yet, this exception is consequential. An examination of the top 15 market leaders (as identified by the InformationSecurity magazine in 2007) in ISM suggests that diversifying entrants as well as hackers perform better relative to all other entrants, while none of the top performers are spinoffs. Of the top 15 market leaders, 6 or about $40 \%$ were hacker founded startups. About a third are incumbent ICT trademarks diversifying into ISM. Both of the top technology suppliers were startups that were founded by university professors.

Table 4 ISM Market leaders

\begin{tabular}{|c|c|c|c|}
\hline Firm name & 2007 sales & Principal founder type & Main Market \\
\hline Network Associates & $\$ 987.30$ & Hacker & Antivirus \\
\hline RSA Data Security & $\$ 138.00$ & University & Encryption technology \\
\hline Symantec & $\$ 5,187.30$ & Hacker & Antivirus \\
\hline Checkpoint & $\$ 687.80$ & Related startup & Firewall \\
\hline Computer Associates & $\$ 595.0^{+}$ & Hacker & Antivirus \\
\hline Cisco & $\$ 665.4^{+}$ & Diversifier & Firewall \\
\hline Aladdin & $\$ 89.00$ & Hacker & Authentication (encryption) \\
\hline Juniper & $\$ 480.0^{+}$ & Diversifier & Network security (encryption) \\
\hline Sybari & $\$ 8.80^{\mathrm{a}}$ & Other & Spam \\
\hline Certicom & $\$ 15.10$ & University & Encryption technology \\
\hline Eeye security & $\$ 11.20^{\mathrm{b}}$ & Hacker & Firewall \\
\hline Secure computing corp & $\$ 176.70$ & Diversifier & Authentication (encryption) \\
\hline Internet Security Systems & $\$ 329.80$ & Hacker & Firewall \\
\hline Entrust & $\$ 138.00$ & Diversifier & Authentication (encryption) \\
\hline Trend Micro & $\$ 618.90$ & Related startup & Antivirus \\
\hline
\end{tabular}




\section{Timing of entry}

In many industries such as automobiles (Klepper, 2002) diversifying entrants were among the first to enter the ISM, while in certain other industries such as disk drives (Christensen, 1997), startups were among the first to enter. There do not appear to be big differences in the mean time of entry between startups and diversifiers. There are no significant differences between the timing of entry between different categories of startups, except that related startups enter ISM later than both diversifiers and other startups. Relative to diversifiers, startups were not only smaller at the time of entry but they also entered the industry with fewer security patents.

Table 5 shows that the internet stimulated the demand for information security, with over $80 \%$ (300 firms of a total of 343 firms) of the firms entering after 1995. The proportion of firms entering downstream segment also increased from just under $50 \%$ pre-internet to nearly $66 \%$ post-internet. Most of this increase is due to startups. Whereas pre-internet, only $36 \%$ of the startups were downstream, post-internet, $66 \%$ were downstream.

In many manufacturing industries although startups constitute the major number of entrants, they are less successful (Dunne et al., 1988). This is true of ISM as well (see table 6). Many previous studies provide insights into the reasons for this superior performance. In some industries such as televisions, such performance advantages are driven by superior R\&D capability (Klepper and Simons, 2000a). In other industries it is driven by superior complementary capability, specifically superior sales and distribution capability (medical imaging - Mitchell, 1989; Disk drives - King and Tucci, 2001). Table 7 shows that diversifying entrants were not only larger at entry, but that they also had more security patents at entry. 
Table 5 - Patterns of entry

\begin{tabular}{ccccccccc}
\hline & \multicolumn{1}{c}{ Before 1995 } & \multicolumn{5}{c}{$1996-2004$} \\
\hline & Upstream & Downstream & Both & Total & Upstream & Downstream & Both & Total \\
Diversifiers & 0 & 11 & 7 & $\mathbf{1 8}$ & 1 & 26 & 12 & $\mathbf{3 9}$ \\
Related & 3 & 3 & 2 & $\mathbf{8}$ & 4 & 104 & 44 & $\mathbf{1 5 4}$ \\
startups & & & & & & & & \\
Other startups & 4 & 3 & 4 & $\mathbf{1 0}$ & 5 & 47 & 28 & $\mathbf{7 9}$ \\
Hacker & 0 & 3 & 4 & $\mathbf{7}$ & 0 & 15 & 13 & $\mathbf{2 8}$ \\
All startups & 7 & 9 & 10 & $\mathbf{2 5}$ & 9 & 166 & 87 & $\mathbf{2 6 1}$ \\
\hline Period Total & 7 & 20 & 17 & $\mathbf{4 3}$ & 10 & 192 & 97 & $\mathbf{3 0 0}$ \\
\hline
\end{tabular}

Table 6 - Size, patents, trademarks at entry and mean time of entrants

\begin{tabular}{|c|c|c|c|c|c|c|}
\hline & Diversifiers & All Startups & $\begin{array}{l}\text { Related } \\
\text { Startups }\end{array}$ & Hackers & $\begin{array}{l}\text { Unrelated } \\
\text { Startups }\end{array}$ & Univ \\
\hline Log size at entry & $\begin{array}{c}4.12 \\
(0.26)\end{array}$ & $\begin{array}{c}3.06 \\
(0.19)\end{array}$ & $\begin{array}{c}3.30 \\
(0.25)\end{array}$ & $\begin{array}{c}3.52 \\
(0.63)\end{array}$ & $\begin{array}{c}1.98 \\
(0.75)\end{array}$ & $\begin{array}{c}3.24 \\
(0.72)\end{array}$ \\
\hline $\log (1+$ sec. patents $)$ at entry & $\begin{array}{c}0.85 \\
(0.12)\end{array}$ & $\begin{array}{c}0.31 \\
(0.05)\end{array}$ & $\begin{array}{c}0.28 \\
(0.08)\end{array}$ & $\begin{array}{c}0.31 \\
(0.17)\end{array}$ & $\begin{array}{c}0.36 \\
(0.14)\end{array}$ & $\begin{array}{c}0.65 \\
(0.19)\end{array}$ \\
\hline Mean year of entry & $\begin{array}{c}1995 \\
(241.67)\end{array}$ & $\begin{array}{c}1995 \\
(48.16)\end{array}$ & $\begin{array}{l}1997 \\
(113)\end{array}$ & $\begin{array}{c}1994 \\
(319.87)\end{array}$ & $\begin{array}{c}1996 \\
(249.42)\end{array}$ & $\begin{array}{c}1994 \\
(320.54)\end{array}$ \\
\hline $\log (1+$ IT trademarks $)$ & $\begin{array}{c}1.13 \\
(0.05)\end{array}$ & - & - & - & - & \\
\hline
\end{tabular}

Notes: Log of IT trademarks is not reported for startups because startups do not have trademarks at the time of entry.

Interestingly in the ISM, diversifying entrants are relatively more successful in the downstream segment (selling only products) suggesting that perhaps such performance advantages are due to superior production or marketing and distribution capabilities (see table 7).

Also, the ISM seems be different from lasers in which spinoffs are successful. In the ISM, spinoffs do not perform as well as diversifying entrants. This is also the case with related startups as well. We explore this further in our empirical analysis.

Table 7 - Proportion of exits by market segment (raw proportions)

\begin{tabular}{cccc}
\hline & Exits & Downstream & Both \\
\hline Diversifiers & 0.14 & 0.11 & 0.20 \\
& $(0.02)$ & $(0.02)$ & $(0.04)$ \\
All startups & 0.26 & 0.28 & 0.19 \\
& $(0.01)$ & $(0.02)$ & $(0.02)$ \\
Spinoffs & 0.22 & 0.15 & 0.17 \\
& $(0.02)$ & $(0.03)$ & $(0.03)$ \\
Related & 0.25 & 0.28 & 0.26 \\
& $(0.03)$ & $(0.02)$ & $(0.02)$ \\
Unrelated & 0.16 & 0.20 & 0.04 \\
& $(0.01)$ & $(0.02)$ & $(0.01)$ \\
\hline
\end{tabular}




\section{Technology and product markets:}

As explained earlier, firms in the sample were classified as technology suppliers, product vendors or both. The technology markets are for encryption, image matching, pattern matching and single sign on technologies. The product markets consist of firewall, antivirus, authentication, encryption, hardware, network security, spam control and consulting.

In our empirical analysis, to conserve degrees of freedom, we consolidate product markets into those that use encryption technologies, and those based on other technologies. The former consists of encryption products, network security, and authentication, while firewalls, antivirus, spam control, hardware and consulting make up the other category. Our results are robust to inclusion of individual market specific fixed effects.

Encryption is by far the most patent intensive ISM technology (Giarratana, 2004). Roughly two thirds of all security patents related to encryption technology. Encryption markets are also more licensing intensive. Table 8 shows the number of patents per entrant and the number of licenses per entrant in ISM. There were almost three times as many licensing transactions per firm in encryption markets relative to other markets. Finally, for a subset of entrants, we were able to trace the source of technology. The last column in table 8 shows that whereas $65 \%$ of the entry in encryption was based on licensed technology, the corresponding figure is only $13 \%$ for the other markets.

Table 8 - Entry by submarket

\begin{tabular}{lccrrrrr}
\hline & Pre 1995 & $\begin{array}{c}1996- \\
2004\end{array}$ & Total & $\begin{array}{c}\text { Security patents } \\
\text { at entry }\end{array}$ & $\begin{array}{c}\text { Licensing } \\
\text { deals per } \\
\text { firm }\end{array}$ & $\begin{array}{c}\text { Upstream } \\
\text { (pure } \\
\text { licensors) }\end{array}$ & $\begin{array}{c}\text { \% entrants } \\
\text { with } \\
\text { licensed } \\
\text { technology }\end{array}$ \\
\hline Encryption & 42 & 174 & 216 & $\begin{array}{r}12.85 \\
(8.75)\end{array}$ & $\begin{array}{r}(0.01) \\
0.69\end{array}$ & 17 & 65 \\
Other markets & 16 & 111 & 127 & $\begin{array}{r}2.69 \\
(11.35)\end{array}$ & $0.02)$ & 0 & 13 \\
\hline
\end{tabular}




\section{Empirical results:}

In order to test hypotheses that relate to how markets for technology condition entry and exit, we exploit the variation across segments (encryption based and non-encryption based) as well variation over time, in the number of specialized licensors. Our benchmark specification uses the number of specialized licensors as a proxy for the extent of competition in the market for technology, and roughly corresponds to $b$ in the theoretical model.

Strictly speaking the number of specialized licensors is endogenous. In our data, virtually all of these are the results of university invented technology being licensed by a startup. University invention may itself be related to characteristics of the underlying technology that are, in turn, related to conditions of entry and exit. We address this concern by using a type of "difference-in-difference" strategy to identify the impact of interest. For instance, in a number of our hypotheses, markets for technology affect different types of entrants differentially. By stressing these differences (in addition to the main effect), we can be more confident that what we see is the hypothesized effect, rather than merely unobserved differences across market segments.

\section{Entry strategy}

We first test the hypotheses related to entry strategy. We use a logit specification in which, the dependent variable downstream, takes a value of 1 if an entrant entered the downstream segment. We use an encryption market dummy to control for unobserved differences across encryption based markets and others. We distinguish between the types of entrants. We use the $\log$ of $(1+I T$ trademarks $)$ as a proxy for the amount of marketing assets of a firm while we use $\log (1+$ Size $)$ as a proxy for scale. Both these variables measure the extent to which, firms can efficiently produce and sell ISM product(s). We also use the log of the citation 
weighted number of security patents to control for technical competence. ${ }^{13}$ In addition we also control for age (and age squared) of the industry and timing of entry - whether entry was before or after internet.

Table 9 shows the results. The key independent variable is the number of technology suppliers, $\log (1+$ tech. suppliers $)$. As noted before this variable varies both between market type, namely encryption vs. non-encryption and also over time. ${ }^{14}$

Specification 1 shows that the number of IT trademarks held by firms at entry is associated with higher proportion of entry into the downstream segment. A $1 \%$ increase in the number of IT trademarks is associated with about a 1.9 times higher probability of entering downstream segment. Specification 2 additionally shows that for size of the firm at time of entry itself increases the conditional probability of downstream entry. ${ }^{15}$ A $1 \%$ increase in size is associated with about a $12 \%$ higher probability of entering downstream segment. Further the ICT dummy in specification 1 suggests that diversifying ICT firms are about 1.8 times more likely to enter downstream segment relative to startups. These findings are consistent with the first prediction, namely that, firms with larger scale, and higher production and marketing capability are more likely to enter downstream, conditional on entry. These results are consistent with Gambardella and Giarratana (2006). By a symmetric argument, these results also suggest that insofar as startups are less efficient, lacking scale and marketing assets, startups are more likely to enter technology markets (Arora and Fosfuri, 2003). The coefficient estimate of $\log (1+$ security patents) is negative and significant. This result also supports the argument that patents

\footnotetext{
${ }^{13}$ Since startups have no complementary assets at the time of entry, this variable takes a value of 0 for startups.

${ }^{14}$ About 26 firms do not report size at the time of entry. We start by not controlling for scale, thereby using all 326 observations. In specification 2 we additionally control for scale along with all the independent variables as in specification 1. However while doing so we lose about 26 observations that relate to firms that do not report number of employees.

${ }^{15}$ Note that we lose 42 observations for which size at entry is not observed in specification 2.
} 
mediate technology sale, and thus encourage firms to also license their technology (Arora and Ceccagnoli, 2006).

Result 2 had implied that an increase in competition in market for technology increases the proportion of entry into the downstream segment. Specifications 1 through 3 show that the number of specialized technology suppliers increases the proportion of downstream entry. From specification 2, a $10 \%$ increase in the number of technology suppliers is associated with a $95 \%$ higher probability of downstream entry. This is consistent with entry by "licensing" in technology. In specification 4, we explore if the presence of markets for technology encourages entry through licensing as implicit in our model. If so, this should be reflected in how technology markets affect the entry of firms without technology. To this end, we divide all entrants into those with at least one security patent at the time of entry and those with none. It is plausible that firms with at least one patent are much more likely to possess technology than those without a patent. We run two separate logistic regressions, one on a sample of firms that at least one patent at the time of entry and another on a sample of firms that had no patents at the time of entry. ${ }^{16}$

\footnotetext{
${ }^{16}$ We use two separate regressions in view of the potential problems with interaction terms in nonlinear regression models (Ai and Norton, 2003).
} 
Table 9- Logit regressions of entry strategy, dependent variable DOWNSTREAM=1

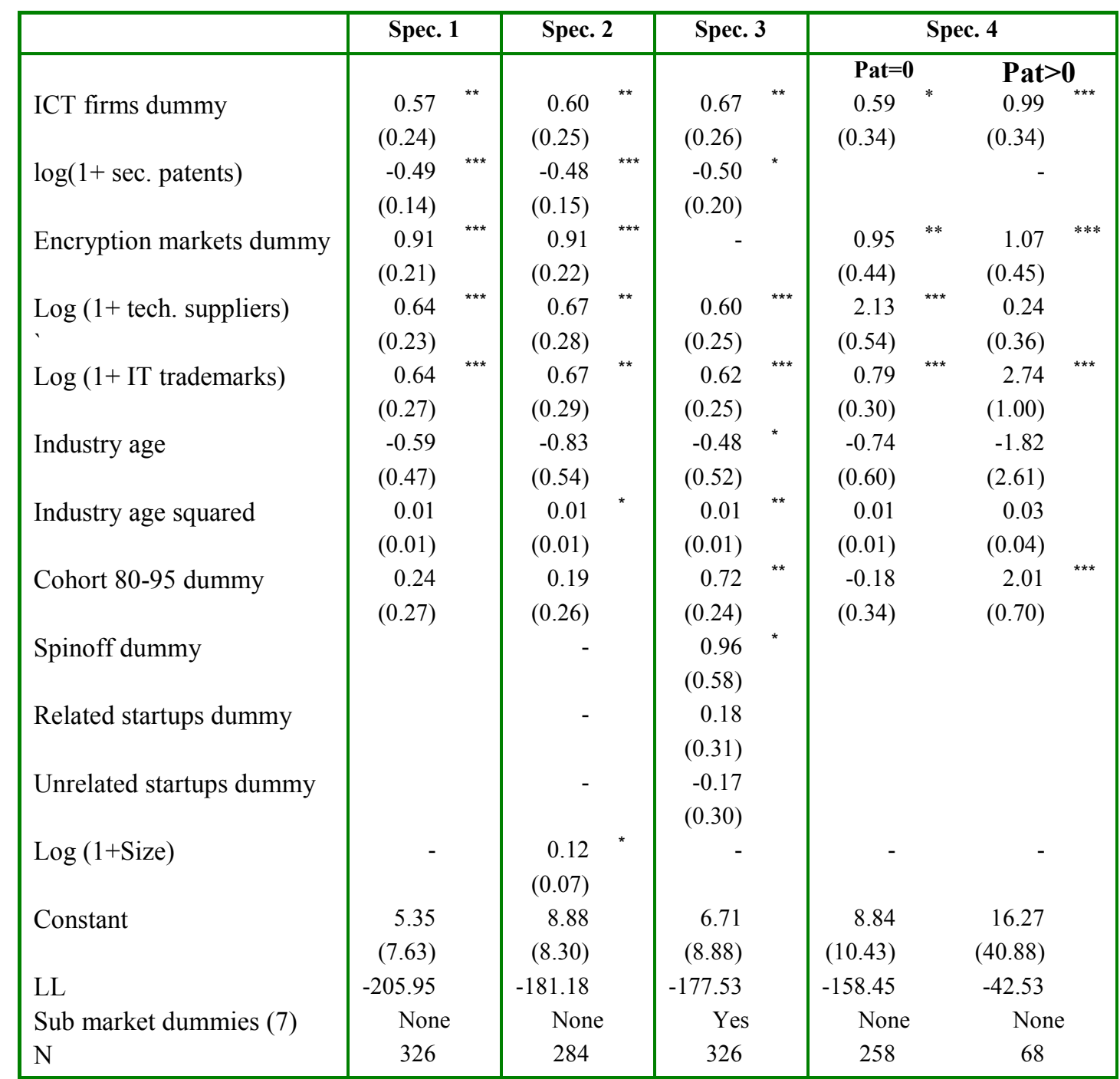

Notes: ***Significant at $1 \%$. ** Significant at 5\%. * Significant at 10\%. Log of IT trademarks for startups is 0 because startups do not have trademarks at the time of entry.

We use the same set of controls as specification 1. The independent variable of interest is the number of technology suppliers. The results imply that an increase in the number of technology suppliers increases the proportion of firms without patents entering downstream, whereas the effect is weaker and statistically insignificant for firms with at least one security patent. The point estimates suggest that among firms without patents, a $1 \%$ increase in technology suppliers increases the proportion of downstream entry by about 8.4 times, whereas 
for patentees, a $1 \%$ increase in technology suppliers decreases the proportion of firms that enter downstream by 1.2 times. The differential impact of markets for technology on firms with and without patents suggests that what our results are picking up is not simply unobserved differences across encryption and other markets, but rather properties of industries with markets for technology. Recall that in our model, an increase in the number of licensors directly increased entry by firms lacking technology, whereas for firms with technology, the effect was to shift firms from a mixed model (both licensing and products) to purely products. Our empirical results suggest that the increased entry of firms without technology is more pronounced than the shift in the business model of entrants with technology.

Of course, firms do not have to buy technology in order to be downstream. The coefficient of ICT dummy suggests that diversifying ICT firms, even when they have patents, are likely to enter downstream and not engage themselves in technology licensing. This is especially true for firms with marketing assets (IT trademarks) and for larger firms. All of this is consistent with the finding in Arora and Ceccagnoli (2005) that patents facilitate licensing, but only firms that lack specialized complementary capabilities.

To summarize, our results suggest that diversifiers are more likely to enter downstream segments. We also find evidence of markets for technology stimulating entry through licensing, especially by firms that have marketing capabilities and scale, while not affecting entry by firms with proprietary technology.

\section{Performance}

In this section, we explore the determinants of performance using Cox proportional hazard regressions of exit. We consider startups at risk of exit from the time the startup was established while diversifying entrants are at risk from the time of entry into ISM. Observations that relate to firms that were still alive at 2004 were considered as censored observations. 
Moreover, we also considered as censored observations where the firm was acquired on friendly terms, excluding distress sales which are treated as exits.

The use of survival as a measure of performance is very common (Klepper and Simons 2000a; Carroll et al.1996; Klepper and Sleeper 2005; Thompson 2005). It is possible, however, that exit decisions of incumbent diversifiers may differ from those of startups. Diversifiers may have deeper pockets, or may be willing to lose a little money in security markets to achieve other goals. On the other hand, startups tend of founders that identify personally with the business and may tend to linger on long after it is clear that the business is not viable. Thus, though exit decisions may depart from the expected profitability of the firm, the resulting bias, if any, is unclear.

We use the same set of firm and market characteristics as before ${ }^{17}$ Additionally, to allow for time and age dependence, we control for the age and square of the age of the firm(using ISM tenure and ISM tenure ${ }^{2}$ ), as well as the whether entry before 1995. Finally, with the exception of specification 2, we also control for the number of producers within the same submarket (competitors) to control for the intensity of competition.

As is the case with many other industries, diversifiers survive longer than startups. In specification 1, diversifiers are almost $80 \%$ less likely to exit relative to startups. Note that all other sources of advantage find support as well. Result 4 implied that scale and marketing assets should improve performance, as should proprietary technology. The estimation results broadly confirm this. A $1 \%$ increase in size is associated with about $18 \%$ decrease in exit hazard, while a $1 \%$ increase in IT trademarks is associated with a $31 \%$ decrease in exit hazard. Having proprietary security technology is beneficial -- a $1 \%$ increase in security patents is associated

\footnotetext{
${ }^{17}$ Also note since 42 (13\%) firms do not report their size, we interact $\log ($ size $)$ with size not reported dummy $=1$ if the firm did not report size.
} 
with $10 \%$ decrease in exit probability, though this effect is not statistically significant. Entry prior to the growth of the internet does not help survival. This suggests that the first mover advantage, if any, must manifest itself in scale, patents or marketing assets.

Results in specification 2 suggest that omitting the number of competitors does not affect our principal results, and our estimate of competition by itself is small and insignificant. This is in part perhaps an artifact of measurement error in our measure of competitors: We do not include multi-product firms that operate in the same submarket. ${ }^{18}$

There are several possible sources of advantage that diversifiers may enjoy: scale economies, which enable firms to undertake larger fixed investments in improving efficiency and lowering cost (Cohen and Klepper, 1992; complementary capabilities (Teece, 1986), superior technology and R\&D capabilities (Klepper and Simons, 2000a), or superior marketing capabilities (Mitchell, 1989). A variant is the suggestion that it is early entry rather than incumbency which matters, because early entry allows more time for growth and the consequent benefits of scale (Klepper, 1996; Klepper and Simons, 2000). Since we control for patents, IT trademarks, and size at entry, and because related startups (including spinoffs from security firms themselves) do not perform better than unrelated startups, it appears that these do not exhaust the sources of this superior operating efficiency. Nor is it due to experience in the ICT industry per se. Though we acknowledge that our proxies for scale, marketing and technology are imperfect, the results potentially point to additional sources of advantage for incumbent firms diversifying into the ISM. These may include superior managerial capability or managerial routines, existing

\footnotetext{
${ }^{18}$ Although we are able to identify the market where the firm initially enters, it is likely that some firms operate in multiple markets thereafter. Thus, our measure of the number of producers in a market is likely to have considerable measurement error. It appears that this error attenuates the estimated coefficient of the number of producers, but does not appear to affect estimates of other variables.
} 
relationships with corporate clients, or superior financial resources. It may also simply reflect strategic differences between diversifiers and startups in the value of "staying on" in the ISM.

Result 3 implies that specialized technology suppliers should increase the average rate of exit from product markets. Indeed, from column 1 a $1 \%$ increase in the number of technology suppliers is associated with about a $2 \%$ increase in exit probability. This is an interesting result. It suggests that though they lower entry barriers and increase entry, by increasing subsequent competition, technology markets do also increase exit.

In specifications 3 and 4 we test result 5 . We interact our measure of the number of technology suppliers with our measures of scale, marketing and proprietary technology. In result 4 we additionally interact the number of technology suppliers with the dummy for ICT diversifiers.

Specification 3 results show that the increase in exit rates is moderated by trademarks and by scale. The results imply that a $1 \%$ increase in IT trademarks is associated with about a $23 \%$ decrease in the hazard of exit in the absence of technology suppliers, whereas a $1 \%$ increase in IT trademarks is associated with about a $65 \%$ decrease in the average hazard of exit for every percentage increase in technology suppliers. Thus every percentage point increase in technology suppliers implies an additional $42 \%$ advantage for every $1 \%$ increase in the ownership of IT trademarks. The estimates with respect to size are similar. In markets that do no have any technology suppliers, a $1 \%$ increase in size implies a $13 \%$ decrease in the average hazard of exit. However, in product markets that have technology suppliers, a $1 \%$ increase in technology suppliers implies an additional 57\% reduction in the average hazard of exit for every percentage point change in size. 
Table 10 Cox proportional Hazard regressions of exit

\begin{tabular}{|c|c|c|c|c|c|c|c|c|c|c|}
\hline & \multicolumn{2}{|c|}{ Spec. 1} & \multicolumn{2}{|c|}{ Spec 2} & \multicolumn{2}{|c|}{ Spec. 3} & \multicolumn{2}{|c|}{ Spec. 4} & \multicolumn{2}{|c|}{ Spec. 5} \\
\hline ICT firms dummy & $\begin{array}{l}-1.38 \\
(0.24)\end{array}$ & & $\begin{array}{l}-1.37 \\
(0.21)\end{array}$ & & $\begin{array}{l}-1.72 \\
(0.21)\end{array}$ & $* \star \star$ & $\begin{array}{l}-2.83 \\
(1.80)\end{array}$ & * & $\begin{array}{l}-1.59 \\
(0.21)\end{array}$ & $* * *$ \\
\hline Competitors & $\begin{array}{l}-0.01 \\
(0.01)\end{array}$ & & - & & $\begin{array}{l}-0.01 \\
(0.01)\end{array}$ & & $\begin{array}{l}-0.01 \\
(0.01)\end{array}$ & & $\begin{array}{l}-0.02 \\
(0.01)\end{array}$ & * \\
\hline Encryption market dummy & $\begin{array}{r}0.35 \\
(0.36)\end{array}$ & & $\begin{array}{r}0.36 \\
(0.42)\end{array}$ & & $\begin{array}{r}0.30 \\
(0.41)\end{array}$ & & $\begin{array}{r}0.36 \\
(0.29)\end{array}$ & & - & \\
\hline $\log (1+$ tech. suppliers $)$ & $\begin{array}{r}0.69 \\
(0.16)\end{array}$ & *** & $\begin{array}{r}0.71 \\
(0.16)\end{array}$ & *** & $\begin{array}{r}1.09 \\
(0.30)\end{array}$ & $* * *$ & $\begin{array}{r}1.07 \\
(0.27)\end{array}$ & * & $\begin{array}{r}0.69 \\
(0.16)\end{array}$ & ** \\
\hline Diversifier* $\log (1+$ tech. suppliers $)$ & - & & - & & & & $\begin{array}{r}0.54 \\
(0.53)\end{array}$ & & - & \\
\hline $\log (1+$ sec. patents $)$ & $\begin{array}{l}-0.10 \\
(0.12)\end{array}$ & & $\begin{array}{l}-0.17 \\
(0.13)\end{array}$ & & $\begin{array}{l}-0.29 \\
(0.56)\end{array}$ & & $\begin{array}{l}-0.22 \\
(0.80)\end{array}$ & & $\begin{array}{l}-0.10 \\
(0.12)\end{array}$ & \\
\hline $\log (1+$ tech supp. $) *(\log (1+$ sec.patents $))$ & - & & - & & $\begin{array}{r}0.13 \\
(0.41)\end{array}$ & & $\begin{array}{r}0.13 \\
(0.39)\end{array}$ & & - & \\
\hline $\log (1+$ IT trademarks $)$ & $\begin{array}{l}-0.36 \\
(0.09)\end{array}$ & $* * *$ & $\begin{array}{l}-0.37 \\
(0.43)\end{array}$ & $* * *$ & $\begin{array}{l}-0.26 \\
(0.20)\end{array}$ & & $\begin{array}{l}-0.21 \\
(0.19)\end{array}$ & & $\begin{array}{l}-0.36 \\
(0.10)\end{array}$ & *** \\
\hline $\log (1+$ tech.supp $) *(\log (1+$ trademarks $))$ & & & & & $\begin{array}{l}-0.29 \\
(0.17)\end{array}$ & * & $\begin{array}{l}-0.31 \\
(0.28)\end{array}$ & & - & \\
\hline Cohort dummy 80-95 & $\begin{array}{r}0.27 \\
(0.29)\end{array}$ & & $\begin{array}{r}0.36 \\
(0.30)\end{array}$ & & $\begin{array}{r}0.34 \\
(0.29)\end{array}$ & & $\begin{array}{r}0.34 \\
(0.26)\end{array}$ & & $\begin{array}{r}0.27 \\
(0.25)\end{array}$ & \\
\hline Size not reported dummy & $\begin{array}{l}-0.44 \\
(0.46)\end{array}$ & & $\begin{array}{l}-0.41 \\
(0.46)\end{array}$ & & $\begin{array}{l}-0.01 \\
(0.21)\end{array}$ & & $\begin{array}{l}-0.01 \\
(0.28)\end{array}$ & $* * *$ & $\begin{array}{l}-0.44 \\
(0.46)\end{array}$ & ** \\
\hline $\log (1+$ tech.suppliers $) * \log ($ size $)$ & & & & & $\begin{array}{l}-0.84 \\
(0.15)\end{array}$ & *** & $\begin{array}{l}-0.84 \\
(0.16)\end{array}$ & $* * *$ & - & \\
\hline$(1-\text { Size not reported)* })^{*} \log ($ size $)$ at entry & $\begin{array}{l}-0.21 \\
(0.03)\end{array}$ & $* * *$ & $\begin{array}{l}-0.19 \\
(0.06)\end{array}$ & $* * *$ & $\begin{array}{l}-0.14 \\
(0.02)\end{array}$ & $* * *$ & $\begin{array}{l}-0.15 \\
(0.02)\end{array}$ & $* * *$ & $\begin{array}{l}-0.20 \\
(0.03)\end{array}$ & *** \\
\hline Spinoff dummy & - & & - & & - & & & & $\begin{array}{l}-0.28 \\
(0.58)\end{array}$ & \\
\hline Related startups dummy & - & & - & & - & & & & $\begin{array}{r}0.09 \\
(0.21)\end{array}$ & \\
\hline Unrelated startups dummy & - & & - & & - & & & & $\begin{array}{l}-0.61 \\
(0.12)\end{array}$ & *** \\
\hline ISM tenure & $\begin{array}{l}-0.27 \\
(0.01)\end{array}$ & *** & $\begin{array}{l}-0.27 \\
(0.01)\end{array}$ & *** & $\begin{array}{l}-0.31 \\
(0.03)\end{array}$ & $* * *$ & $\begin{array}{l}-0.31 \\
(0.03)\end{array}$ & $* * *$ & $\begin{array}{l}-0.31 \\
(0.03)\end{array}$ & *** \\
\hline ISM tenure $^{2}$ & $\begin{array}{l}-0.01 \\
(0.00)\end{array}$ & $* * *$ & $\begin{array}{l}-0.01 \\
(0.00)\end{array}$ & $* * *$ & $\begin{array}{l}-0.01 \\
(0.00)\end{array}$ & $* * *$ & $\begin{array}{l}-0.01 \\
(0.00)\end{array}$ & $* * *$ & $\begin{array}{l}-0.01 \\
(0.00)\end{array}$ & *** \\
\hline $\begin{array}{l}\mathrm{N} \\
\text { Sub market dummies(7) } \\
\text { LL }\end{array}$ & $\begin{array}{r}326 \\
\text { None } \\
-337.15\end{array}$ & & $\begin{array}{r}326 \\
\text { None } \\
-339.77\end{array}$ & & $\begin{array}{r}326 \\
\text { None } \\
-332.54\end{array}$ & & $\begin{array}{r}326 \\
\text { None } \\
-332.51\end{array}$ & & $\begin{array}{r}326 \\
\text { Yes } \\
-335.73\end{array}$ & \\
\hline
\end{tabular}

Notes: $* * *$ Significant at $1 \%$. $* *$ Significant at $5 \% . *$ Significant at $10 \%$. Startups have no trademarks at entry.

The interaction between patent and technology suppliers is, however, small and insignificant. When we further interact diversifiers and technology suppliers (specification 4), the estimated coefficient of the interaction between IT trademarks and technology suppliers is 
statistically insignificant. Other results however do not change much. That the impact of markets for technology differs by scale and marketing assets confirms the predictions of Result 5 . Equally important, it provides reassurance that what we are measuring is not simply the result of unobserved differences across markets.

Our findings on performance by different types of entrants also reinforce the findings in the literature. First, diversifying entrants perform better than startups. This finding is very similar to similar findings in other industries such as automobiles (Carroll et at 1996), televisions (Klepper \& Simmons 2000) and ship-building (Thompson 2002). We find that markets for technology magnify the importance of these other assets, particularly scale and marketing assets. Intuitively, where well-functioning technology markets exist, operational efficiency becomes even more relevant for performance.

\section{Robustness and alternative explanations:}

It is possible that our estimates are picking up the heterogeneity between entrant types not adequately controlled for in the regressions. We explore if this affects our principal results of interest using specifications 3 of table 9 and specification 5 of table 10. In both these specifications, we control for different types of entrants not simply between diversifying ICT firms and startups. Our principal results are substantively unchanged, suggesting that the heterogeneity if any between different entrants do not significantly bias our estimates. However, in the performance regression, in which, we also distinguish among the different types of startups (specification 5 of table 10), indicates two other surprising effects of prior experience. Contrary to expectations, spinoffs and startups founded by employees of ICT firms do not perform as well as unrelated startups. Startups founded by founders from unrelated industries perform markedly better than all other types of startups, albeit not as well as diversifiers. These results suggest that 
prior operational experience of diversifying ICT firms perhaps does not explain why diversifiers perform better. We discuss this finding in greater detail below.

Next, we test the robustness of our results with respect the hypotheses that relate to market for technology. A possible concern is that our estimates reflect unobserved differences between the various market segments. To address this concern, we estimated the differences in the entry strategy of firms with and without patents, and how the presence of technology suppliers differentially affected the entry strategy of these groups. To further explore the robustness of our results, especially those that relate to Result 2, we identified if firms within the encryption market (authentication and network security submarkets) entered by licensing an encryption technology at the time of entry (licensee $=1$ ) or not (licensee $=0)$. Of a total of 216 firms in encryption based product markets, we were able to identify this for a sub-sample of 20 firms. Of these, 20 firms do not report their size. Hence we use 100 observations in the regression that relates to entry strategy, while we use 120 observations in the survival regression. This sample has similar characteristics (not reported here) as the sample of all firms in the encryption market.

We first test if increased competition in encryption technology market encourages firms to enter the ISM by licensing an encryption technology. Since the decision to license and entering downstream segment may be simultaneously determined, we implement a bivariate probit regression (results presented in table 11) in which, the dependent variables are downstream and licensee. Using $\log (1+$ security patents $)$ we also test if licensees are firms that do not have a proprietary technology of their own in the licensor equation. 
Table 11 Results with observed source of technology, encryption market only

\begin{tabular}{|c|c|c|c|c|c|c|}
\hline \multirow[b]{3}{*}{ ICT firms dummy } & \multicolumn{4}{|c|}{ Entry: Bivariate probit regression } & \multicolumn{2}{|c|}{$\begin{array}{l}\text { Exit: Cox prop } \\
\text { regression }\end{array}$} \\
\hline & \multicolumn{2}{|c|}{ DOWNSTREAM=1 } & \multicolumn{2}{|c|}{ LICENSEE $=1$} & & \\
\hline & $\begin{array}{r}0.61 \\
(0.14)\end{array}$ & & $\begin{array}{r}0.19 \\
(0.14)\end{array}$ & & $\begin{array}{l}-1.53 \\
(0.87)\end{array}$ & $*$ \\
\hline Competitors & - & & - & & $\begin{array}{r}-0.01 \\
(0.01)\end{array}$ & \\
\hline $\log (1+$ tech. suppliers $)$ & $\begin{array}{r}-0.07 \\
(0.09)\end{array}$ & & $\begin{array}{r}0.15 \\
(0.09)\end{array}$ & & $\begin{array}{r}1.87 \\
(0.88)\end{array}$ & $* *$ \\
\hline Licencees & - & & - & & $\begin{array}{r}1.21 \\
(0.69)\end{array}$ & $*$ \\
\hline Licensee $* \log (1+$ tech.supp. $)$ & $(0.09)$ & & $(0.09)$ & & $\begin{array}{r}-0.88 \\
(0.23)\end{array}$ & $* * *$ \\
\hline $\log (1+$ sec. patents $)$ & $\begin{array}{r}-0.39 \\
(0.21)\end{array}$ & ** & $\begin{array}{r}-0.11 \\
(0.03)\end{array}$ & $* * *$ & $\begin{array}{r}-0.43 \\
(0.19)\end{array}$ & $* *$ \\
\hline Log $(1+$ IT trademarks $)$ & $\begin{array}{r}0.59 \\
(0.03)\end{array}$ & $* * *$ & $\begin{array}{r}0.05 \\
(0.05)\end{array}$ & & $\begin{array}{r}-0.28 \\
(0.17)\end{array}$ & $*$ \\
\hline ISM tenure & - & & & & $\begin{array}{r}-0.24 \\
(0.13)\end{array}$ & $* * *$ \\
\hline ISM tenure2 & - & & & & $\begin{array}{r}-0.02 \\
(0.00)\end{array}$ & $* * *$ \\
\hline Cohort 80-95 dummy & $\begin{array}{l}-0.49 \\
(0.74)\end{array}$ & & $\begin{array}{l}-0.35 \\
(0.34)\end{array}$ & & $\begin{array}{r}0.59 \\
(0.91)\end{array}$ & \\
\hline Industry age & $\begin{array}{r}-8.40 \\
(0.27)\end{array}$ & $* * *$ & $\begin{array}{r}-0.09 \\
(0.32)\end{array}$ & & - & \\
\hline Industry age squared & $\begin{array}{r}0.13 \\
(0.00)\end{array}$ & $* * *$ & $\begin{array}{l}0.001 \\
(0.00)\end{array}$ & & - & \\
\hline no size dummy & - & & - & & $\begin{array}{r}0.25 \\
(0.36)\end{array}$ & \\
\hline $\log (1+$ Size $)$ & $\begin{array}{r}0.06 \\
(0.05)\end{array}$ & & $\begin{array}{r}0.21 \\
(0.03)\end{array}$ & $* * *$ & $\begin{array}{r}-1.90 \\
(0.42)\end{array}$ & $* * *$ \\
\hline Related startups & $\begin{array}{r}0.77 \\
(0.07)\end{array}$ & $* * *$ & $\begin{array}{r}0.01 \\
(0.04)\end{array}$ & & $\begin{array}{r}0.19 \\
(0.37)\end{array}$ & \\
\hline Spinoff dummy & $\begin{array}{r}0.09 \\
(0.17)\end{array}$ & & $\begin{array}{l}-0.18 \\
(0.07)\end{array}$ & & $\begin{array}{r}-1.36 \\
(0.62)\end{array}$ & $* * *$ \\
\hline Unrelated dummy & $\begin{array}{r}0.21 \\
(0.03)\end{array}$ & $* * *$ & $\begin{array}{r}-0.29 \\
(0.08)\end{array}$ & $* * *$ & $\begin{array}{r}-0.58 \\
(0.36)\end{array}$ & $*$ \\
\hline Constant & $\begin{array}{l}131.8 \\
(3.87)\end{array}$ & $* * *$ & $\begin{array}{r}-1.39 \\
(5.09)\end{array}$ & & - & \\
\hline LL & & -110.8 & & & -82 & 52 \\
\hline Sub market dummies (7) & & None & & & & \\
\hline $\mathrm{P}$ & & $\begin{array}{l}0.05 * \\
(0.03)\end{array}$ & & & - & \\
\hline $\mathrm{N}$ & & 100 & & & 12 & \\
\hline
\end{tabular}

Notes: ${ }^{* * *}$ Significant at $1 \% .{ }^{* *}$ Significant at $5 \% .{ }^{*}$ Significant at $10 \% .20$ firms in this sample do not report size at entry. 
The results reinforce the results on entry discussed earlier. In the licensee equation, the coefficient of technology suppliers is positive and significant suggesting that the number of technology suppliers encourage entry by licensing. The coefficient of $\log (1+$ security patents $)$ is negative and significant, reinforcing the finding that firms with proprietary technology are less likely to enter by licensing. The coefficient estimate of ICT firms dummy is positive, albeit marginally significant, suggesting diversifying ICT firms are more likely to enter by licensing. The results of the downstream equation reinforce the principal results stated in the previous section. Since these results are only for encryption based markets, they suggest that the role of unobserved heterogeneity across markets, if any, do not significantly bias the principal results presented in the previous section.

We then test the robustness of our performance results. We use the same set of controls as in table 10. In addition we use licensee dummy as well as licensee dummy interacted with $\log (1+$ tech. suppliers $)$. The results, shown in column 2 of table 11, reinforce our main findings. The number of technology suppliers increases the hazard of exit on an average. Moreover, licensees perform well only when they are many technology suppliers. Once again, these results suggest that it is unlikely that our principal findings are driven by unobserved differences between encryption and non-encryption markets but rather due to the effects of market for technology.

\section{Discussion and conclusion}

Our results from the analysis of entry and exit in ISM confirm the principal findings in the literature, but also provide some interesting avenues for further research. They confirm the independent role of technology, marketing, and scale in facilitating performance and conditioning entry. Despite this, differences in the type of entrant have large effects in both 
entry and exit. In particular, diversifiers outperform startups, including spinoffs and startups from related industries, indicating that incumbent firms diversifying into a new industry bring not just size, marketing assets, proprietary technology and experience, but also something else, which appears conditions entry strategy and to confer significant survival benefit.

This is corroborated by how entry and survival respond to the presence of markets for technology, which appear to enhance the advantages of operational efficiency, whose source we conjecture may lie in superior firm-routines (for instance, to maintain and upgrade products), superior management ability, or perhaps superior relationships with existing customers.

The source of the advantages enjoyed by incumbent ICT firms diversifying into information security markets cannot be conclusively answered. Not only do we fail to measure all the possible sources of advantage, but those that we do measure, we measure only imperfectly. Trademarks may not capture all important elements of marketing assets, such as the quality of the sales and marketing teams, existing relationships with customers, or the level of branding. Similarly, patents are but one manifestation of the technology. Clever virus researchers rarely produce patentable technology. Yet, without their ability to detect and counter new viruses and worms, the scanning and pattern matching technology that underpins anti-virus products (and which is patentable) would not be very useful.

Even with these qualifications our results point to some interesting avenues for further research. In particular, the finding that firms founded by founders from unrelated industries perform better than other startups, including those with founders with ICT experience, as well as spinoffs from information security firms themselves, requires further exploration. We conjecture that the ISM differs from many of the industries studied by other scholars in the area of entrepreneurship in several important aspects. The first is the absence of manufacturing. 
Although software products must be scaled up, maintained and enhanced, they do not require the large fixed investments of manufacturing, the reduction of production costs for performance, or the associated benefit of manufacturing experience. Undoubtedly, this is an important reason that unrelated startups can succeed.

Second, the widespread use of information technology and the relative ease of obtaining raw material for R\&D (such as access to computers and software) perhaps allows individuals that do not have technical expertise to tinker with existing software in order to develop valuable ideas. One can perhaps draw parallels to the success of private inventors such as Edison at the turn of the century. We speculate that the nature of the industry makes it possible for entrepreneurs with meager resources to tinker, develop innovations, and in some cases, hold more than hold their own against larger, established rivals. It may also be that software offers the possibility of creating many more niches as compared with manufactured products, perhaps because one does not need large fixed investments in manufacturing.

Third, the lack of success enjoyed by related startups and spinoffs as compared to startups from other backgrounds is also intriguing, particularly since other researchers have found a very significant role for pre-entry industry experience. We conjecture that this reflects the general purpose nature of software technologies. Banks, insurance firms, government organizations - all are likely to have substantial in-house capability for information security. Thus, they are also plausibly potent sources for creating new firms dealing with information security. In this, ISM may differ from products such as televisions, radios, and automobiles, though perhaps not lasers.

Fourth, differences in the nature of demand across encryption and other markets may also be important. Economists frequently assume, implicitly or otherwise, that buyers are households. Though households do buy anti-virus and spam control products, network security products 
(such as VPN) are largely bought by businesses. In their purchase decisions, the price and quality of the product are not the only considerations; businesses also place considerable weight on the reputation and reliability of the seller, and whether they have established business relationships with the seller. Thus, it is perhaps not surprising that even individuals without significant technical experience but perhaps with superior technical skills and more importantly a willingness to monitor and respond to ongoing developments (such as the release of new viruses and worms) could break into markets where households are an important source of demand. ${ }^{19}$ However, established firms would hold sway in markets dominated by business buyers, particularly if they could get access to technology via a market for technology, as is true for encryption products.

Finally, the most important insights from our results are in the impact of the vertical structure of the industry on entry and exit. Specifically, our research shows how markets for technology conditions entry, exit and competition. Markets for technology encourage vertical specialization and increases entry, especially by firms that do not have proprietary technology. However, a competitive technology market also stimulates competition in the related product market and increases exit rates. In particular markets for technology increase the relative importance of hardto-replicate-assets such as marketing ability and scale, while they hasten exit by firms that do not hold these assets.

\footnotetext{
${ }^{19}$ In firewalls, the ability to sell an "add-on" product, rather than one that would be deeply embedded in the buyer's network infrastructure also helped.
} 


\section{References:}

Anton, James J., and Dennis Yao. 1995. "Start-ups, Spin-.ffs, and Internal Projects." Journal of Law, Economics and Organization 11 (2):362-378.

Arora, A. and Ceccagnoli, M., 2006. 'Patent Protection, Complementary Assets, and Firms' Incentives for Technology Licensing". Management Science, 52:293-308 , Fosfuri, A. and Gambardella, A., 2001. "Markets for Technology and their Implications for Corporate Strategy". Industrial and Corporate Change, 10(2): 419-451 , Fosfuri. 2003. "Licensing the market for technology". Journal of Economic Behavior and Organization, 52:277-295.

Barney, J. B. 1991. "Firm resources and sustained competitive advantage". Journal of Management, 17(1): 99-120.

Breznitz, D. 2007. "Innovation and the state: Political choice and strategies for growth in Israel, Taiwan, and Ireland. New Haven, CT" Yale University Press.

Carroll, Glenn R., Bigelow, Lyda S., Seidel, Marc-David L. and Tsai, Lucia B. 1996. "The Fates of De Novo and De Alio Producers in the American Automobile Industry 18851981.Strategic Management Journal, 17 (S1):117-137.

Chang, S. J. 1997. "An Evolutionary Perspective on Diversification and Corporate Restructuring:Entry, Exit, and Economic Performance During 1981-89," Strategic Management Journal, 17:587-612.

Chatterjee, S. and B. Wernerfelt ,1991, "The Link Between Resources and Type of Diversification: Theory and Evidence". Strategic Management Journal. 12:33-48.

Chatterji, A., 2006. "Spawned with silver Spoon? Entrepreneurial Performance and Innovation in the Medical Device Industry", Unpublished manuscript, University of California at Berkeley.

Christensen, C. M. 1997, “The Innovator's Dilemma”. Harvard Business School Press: Cambridge, MA.

Cohen, W. and Klepper, Steven, 1992. "The Anatomy of Industry R\&D Intensity Distributions" The American Economic Review, 82( 4):773-799.

Dunne, T., M. Roberts, L. Samuelson, 1988. "Patterns of entry and exit in U.S. manufacturing industries". Rand Journal of Economics 19:495-515.

Dierickx. I. and K. Cool. 1989. "Asset stock accumulation and sustainability of competitive advantage". Management Science. 35:1504-1511.

Gambardella, A. and Giarratana, M., 2006. "Innovations for products, Innovations for licensing: Patents and downstream assets in the software industry" working paper available at SSRN: http://ssrn.com/abstract $=935210$

Gans, Joshua. S., David H. Hsu and Stern, Scott. 2002. "When Does Start-Up Innovation Spur the Gale of Creative Destruction? The RAND Journal of Economics, 33(4):571-586.

Giarratana M.S. 2004. "The birth of a new industry: Entry by start-ups and the drivers of firm growth: The case of encryption software" Research Policy, 33 (5):787-806.

Geroski, Paul. A. 1995. "What do we know about Entry" International Journal of Industrial Organization, 13 (4):421-440.

Helfat, E. Constane and Lieberman, Marvin. B. 2002. "The birth of capabilities: market entry and the importance of pre-history". Industrial and Corporate Change, 11(4): 725-760.

Hellmann Thomas, 2006. "When Do Employees Become Entrepreneurs?" Management Science, 53(6): 919-933.

Jovanovic, B. 1982. "Selection and evolution of industry". Econometrica, 50(3): 649-670. 
King, A. and C. L. Tucci (2001). "Incumbent Entry into New Market Niches: The Role of Experience and Managerial Choice in the Creation of Dynamic Capabilities" mimeo, New York University.

Klepper, Steven, 1996.“Entry, Exit, Growth, and Innovation over the Product Life Cycle. American Economic Review, 86(1996):562-583. and Simons, K.L. 2000. "The Making of an Oligopoly: Firm Survival and Technological Change in the Evolution of the U.S. Tire Industry". Journal of Political Economy, 108: 728-760. and 2000a. "Dominance by birthright: entry of prior radio producers and competitive ramifications in the U.S. television receiver industry". Strategic Management Journal, 21: 997-1016. 2002. "The capabilities of new firms and the evolution of the US automobile industry". Industrial and Corporate Change 11:645-666. and Sleeper, S. 2005. "Entry by spinoffs", Management Science 51(8):1291-1306. and Thompson, P. 2005. "Spinoff Entry in High-tech Industries: Motives and Consequences," Working Papers 0503, Florida International U.niversity, Department of Economics

Markides C. Constantinos and Williamson, Peter, J. 1996. "Corporate Diversification and Organizational Structure: A Resource-Based View" The Academy of Management Journal, Vol. 39(2):340-367.

Merino, F. and D. R. Rodriguez 1997, “A Consistent Analysis of Diversification Decisions with Non-observable Firm Effects" Strategic Management Journal, 18:733-744.

Mitchell, W. 1989. "Whether and When? Probability and Timing of Incumbents' Entry into Emerging Industrial Subfields" Administrative Science Quarterly, 34(2):208-230. 1991. "Dual Clocks: Entry Order Influences on Incumbent and Newcomer Market Share and Survival When Specialized Assets Retain Their Value". Strategic Management Journal, 12(2): 85-100.

Nelson, Richard R. and Sidney G. Winter, 1982. "An Evolutionary Theory of Economic Change”. ,Harvard University Press, Cambridge, MA.

Silverman, B. S. 1999, "Technological Resources and the Direction of Corporate Diversification: Toward an Integration of the Resource-Based View and Transaction Cost Economics". Management Science, 45: 1109-1124.

Sleeper, S. D. 1998, "The role of firm capabilities in the evolution of the laser industry: the making of a high-tech market”. Ph.D. dissertation, Carnegie Mellon University.

Teece, D. 1986. Profiting from technological innovation: Implications for integration, collaboration, licensing and public policy. Research Policy. 15: 285-305

Thompson, P. 2005. "Selection and Firm Survival: Evidence from the Shipbuilding Industry, 1825-1914" Review of Economics and Statistics, 87(1): 26-36.

Trajtenberg, M. 1990. "A Penny for Your Quotes: Patent Citations and the Value of Innovations". The RAND Journal of Economics, 21(1):172-187.

Tripsas, M. 1997, "Unraveling the process of creative destruction: complementary assets and incumbent survival in the typesetter industry". Strategic Management Journal, 18:119142. 


\section{Appendix 1 Proof of propositions}

\section{Appendix :}

We begin by characterizing the equilibrium and signing the impact of an increase in $b$ on $p$ and M. It is helpful to characterize the relationship between $p$ and $\mathrm{M}$ implied by equilibrium in the product market (the PP curve) and the licensing market (TT curve).

1. The PP curve is downward sloping and TT curve is upward sloping.

Let $X \equiv \frac{L-E}{\gamma} ; Y \equiv \frac{\theta}{p-c-\gamma} ; Z \equiv \frac{\theta+\tau}{p-c}$

$h_{1} \equiv h((p-c) q-\theta) ; h_{2} \equiv h((p-c-\gamma) q-\theta) ; H_{1} \equiv H((p-c) q-\theta) ; H_{2} \equiv H((p-c-\gamma) q-\theta)$ (A2)

We have at 2 equations

$$
\begin{aligned}
& D(p)-T\left[\frac{\lambda}{1-F(X)} \int_{X}^{\infty} q H_{1} d F+\frac{\lambda}{F(X)-F(Y)} \int_{Y}^{X} q H_{2} d F+\frac{1-\lambda}{1-F(Z)} \int_{Z}^{\infty} q H_{1} d F\right]=0 \\
& M-T \lambda F(X)-b=0
\end{aligned}
$$

with $L=\frac{T(1-\lambda) \tau}{M}(1-F(Z))$.

The endogenous variables are $p$ and $M$. Let $A_{11}, A_{12}$ denote the partial derivatives of (A3) with respect to $\mathrm{p}$ and $\mathrm{M}$ respectively, and likewise $\mathrm{A}_{21}, \mathrm{~A}_{22}$ from (A4). we have, $\mathrm{A}_{11} \mathrm{dp}+\mathrm{A}_{12} \mathrm{dM}=0$ and $\mathrm{A}_{21} \mathrm{dp}+\mathrm{A}_{22} \mathrm{dM}=0$.

$$
A_{11}=D^{\prime}(p)-T\left\{\begin{array}{l}
\frac{\lambda}{1-F(X)}\left[\frac{\partial L}{\partial p} f(X)\left(-X H_{1}(X)+\int_{X}^{\infty} \frac{q H_{1} d F}{1-F(X)}\right)+\int_{0}^{\infty} q^{2} h_{1} d F\right] \\
\left.\frac{\lambda}{F(X)-F(Y)}\left[\frac{f(Y) \theta}{(p-c-\gamma)^{2}}\left(Y H_{2}(Y)+\int_{Y}^{X} \frac{q H_{2} d F}{F(X)-F(Y)}\right)+\frac{\partial L}{\partial p} f(X)\left(X H_{2}(X)+\int_{Y}^{X} \frac{q H_{2} d F}{F(X)-F(Y)}\right)\right]\right\}<0 \\
+\frac{(1-\lambda)}{(1-F(Z)}\left[\frac{f(Z)}{(p-c)}\left(Z^{2} H_{1}(Z)+\int_{Z}^{\infty} \frac{q H_{1} d F}{1-F(Z)} Z\right)+\int_{Z}^{\infty} q^{2} h_{1} d F\right]
\end{array}\right\}
$$

Note that $X H_{1}(X)<\frac{1}{1-F(X)} \int_{X}^{\infty} q H_{1} d F$ because $\mathrm{X}$ is the lower limit of integration and the term inside the integral sign is monotone increasing function of $\mathrm{q}$.

Thus, $A_{12}=-T\left\{\frac{(1-\lambda) \tau_{M}^{\prime} f(Z)}{(1-F(Z)(p-c)}\left[\left(Z H_{1}(Z)-\int_{Z}^{\infty} \frac{q H_{1} d F}{1-F(Z)}\right)\right]\right\}<0$ 
Similarly, $Z H_{1}(Z)<\frac{1}{1-F(Z)} \int_{Z}^{\infty} q H_{1} d F$ and $\tau_{\mathrm{M}}<0$. Thus $\left.\frac{d M}{d p}\right|_{P P}=-\frac{A_{11}}{A 12}<0$

Turning to the TT curve, observe that $A_{21}=-T \lambda \frac{f(X)}{\gamma} \frac{\partial L}{\partial p}<0$ because

$\frac{\partial L}{\partial p}=\frac{T(1-\lambda)}{M(p-c)} f(Z) Z>0$

To sign $\mathrm{A}_{22}$ we assume that $\frac{p-c}{\theta+\tau}>-\frac{f(Z)}{1-F(Z)}$ or $\frac{-Z f(Z)}{1-F(Z)}<1$. Note that $\frac{-Z f(Z)}{1-F(Z)}$ is the elasticity of $(1-F(Z))$ w.r.t. Z.

$A_{22}=1-T \lambda \frac{f(X)}{\gamma} \frac{\partial L}{\partial M}$. Note that $\frac{\partial L}{\partial M}=\frac{T(1-\lambda)\left[M \tau^{\prime}{ }_{M}\left(\frac{-\tau f(Z)}{p-c}+(1-F(Z))\right)-\tau(1-F(Z))\right]}{M^{2}}<0$

iff $\frac{p-c}{\tau}>\frac{f(Z)}{1-F(Z)}$, which in turn is implied by $\frac{p-c}{\theta+\tau}>\frac{f(Z)}{1-F(Z)}$. This implies $\mathrm{A}_{22}>0$.

Thus $\left.\frac{d M}{d p}\right|_{T T}=-\frac{A_{21}}{A_{22}}>0$

Stability requires $|\mathrm{H}|>0$ i.e., $\mathrm{A}_{11} \mathrm{~A}_{22}>\mathrm{A}_{21} \mathrm{~A}_{12}$, which is satisfied.

2. Next we show that $\frac{d p}{d b}<0$

Let $\mathrm{A}_{1 \mathrm{~b}}$ be the partial derivative of (1) with respect to $\mathrm{b}$.

$$
A_{1 b}=T\left\{\frac{(1-\lambda) \tau_{b}^{\prime} f(Z)}{(1-F(Z)(p-c)}\left[\left(Z H_{1}(Z)-\int_{Z}^{\infty} \frac{q H_{1} d F}{1-F(Z)}\right)\right]\right\}<0
$$

Let $A_{2 b}$ be the partial derivative of (2) with respect to $b$.

$$
A_{2 b}=-1
$$

Thus $\frac{d p}{d b}=\frac{A_{1 b} A_{22}-A_{2 b} A_{12}}{|H|}<0$

3. Next we show that $\frac{d L}{d b}<0$

Note that $\frac{\partial M}{\partial L}=T \lambda f(X)$. Totally differentiating L, we obtain 
$d L(T \lambda f(X)(L+T(1-\lambda) \tau(1-F(Z)))+M)=\tau_{b}^{\prime}\left[T(1-\lambda) M\left((1-F(Z))-\frac{\tau f(Z)}{p-c}\right)\right] d b$

Since, $\frac{p-c}{\theta+\tau}>\frac{f(Z)}{1-F(Z)}, \frac{d L}{d b}<0$.

4. Next we show that $\frac{d M}{d b}>0$

Using equation A4 and totally differentiating it w.r.t b we obtain

$$
d M\left(1-T \lambda \frac{f(X)}{\gamma} \frac{\partial L}{\partial M}\right)=d b, \text { which implies that } \frac{d M}{d b}=\frac{1}{1-T \lambda \frac{f(X)}{\gamma} \frac{\partial L}{\partial M}}>0 \text { since } \frac{\partial L}{\partial M}<0
$$

5. Result 1 is obvious from figure 1 and the proof is omitted.

6. Proof of result 2

For firms with technology $\operatorname{Pr}($ downstream $\mid$ entry $) \equiv \phi=\lambda(1-\mathrm{F}(\mathrm{X}))$

$$
\frac{\partial \phi}{\partial b}=-\lambda f(X) \frac{\partial L}{\partial b}>0
$$

Firms that enter through licensing by definition enter downstream. Therefore, if there is an increase in the probability of entry of firms without technology, the overall proportion of entrants entering downstream must increase.

To see that entry by firms without technology increases, note that an increase in $b$ lowers $p$. For $\mathrm{p}$ to fall there has to be additional production in the product market. This increase in production cannot be due to firms with technology, since their expected profits in the product market are lower, and lower prices will not imply additional entry of firms endowed with technology. Therefore, it must be due to entry of firms without technology.

\section{Proof of result 3:}

The exit probability of exit conditional entry, averaged over firms of different sizes is

$$
\operatorname{Pr}(\text { Exit }) \equiv \frac{\lambda}{1-F(X)} \int_{X}^{\infty}\left(1-H_{1}\right) d F+\frac{\lambda}{F(X)-F(Y)} \int_{Y}^{X}\left(1-H_{2}\right) d F+\frac{1-\lambda}{1-F(Z)} \int_{Z}^{\infty}\left(1-H_{1}\right) d F
$$




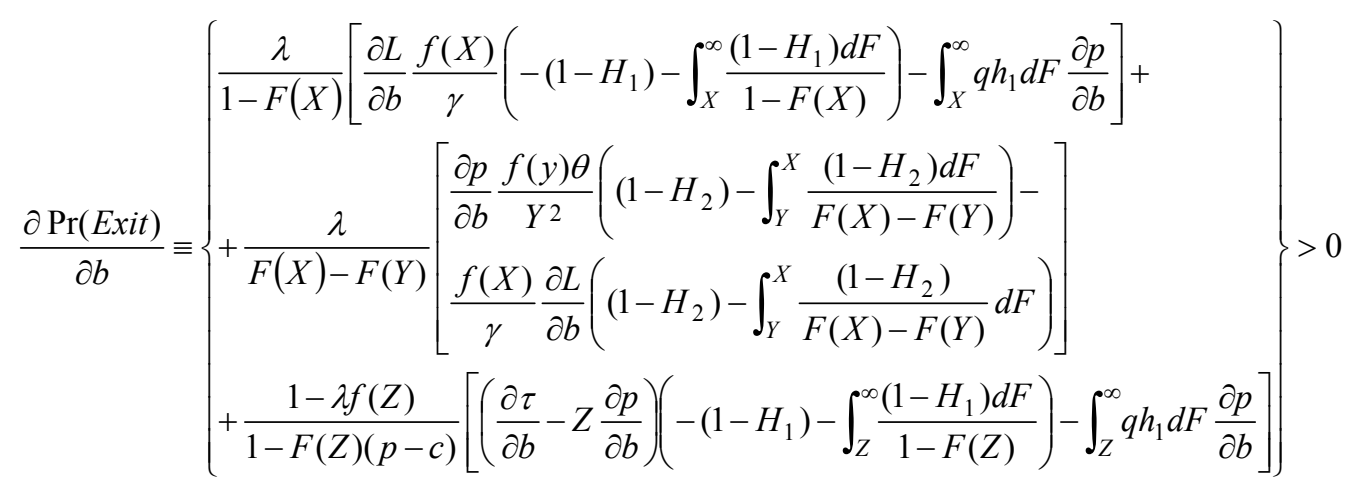

Note that $\left(1-H_{2}\right)-\int_{Y}^{X} \frac{\left(1-H_{2}\right) d F}{F(X)-F(Y)}=0$ and

$\frac{\partial L}{\partial b}<0$ and $\frac{\partial \tau}{\partial b}-Z \frac{\partial p}{\partial b}<0$, as shown below.

Consider entry for firms that do not have a technology of their own. The proof of result 2 established that a firms without technology of their own are more likely to enter when $b$ increases. Implicitly this means that $\frac{\partial E n t r y}{\partial b}=-\frac{f(Z)}{p-c}\left(\frac{\partial \tau}{\partial b}-Z \frac{\partial p}{\partial b}\right)>0$ or $\frac{\partial \tau}{\partial b}-Z \frac{\partial p}{\partial b}<0$.

Hence $\frac{\partial \operatorname{Pr}(\text { Exit })}{\partial b}>0$

\section{Proof of result 4}

For a given $\mathrm{q} \operatorname{Pr}($ Exit $) \equiv\left(1-H_{1}\right)+\left(1-H_{2}\right)$

$$
\frac{\partial \operatorname{Pr}(\text { Exit })}{\partial q}=-\left(h_{1}(p-c)+h_{2}(p-c-\gamma)\right)<0
$$

\section{Proof of result 5}

$$
\frac{\partial \operatorname{Pr}(\text { Exit })}{\partial q \partial b}=-\frac{\partial p}{\partial b}\left((p-c) q h_{1}{ }^{\prime}+(p-c-\gamma) q h_{2}{ }^{\prime}+h_{1}+h_{2}\right)<0
$$

Where $h_{1}$ ' and $h_{2}$ ' are the partial derivatives w.r.t $h_{1}$ and $h_{2}$ respectively. This result is true for many distributions such as normal and exponential where the pdf's are differentiable (instances provided below). 
Case 1 : If $\varepsilon$ is distributed as exponential then $h_{1}=\frac{1}{\beta} e^{-\left(\frac{y}{\beta}\right)}$ where $y \equiv(p-c) q-\theta$ and $\beta$, a constant $>0 . h_{1}{ }^{\prime}=-\frac{1}{\beta^{2}} e^{-\left(\frac{y}{\beta}\right)}<0$. Similarly $h_{2}=\frac{1}{\beta} e^{-\left(\frac{m}{\beta}\right)}$ where $m \equiv(p-c-\gamma) q-\theta$.

Therefore $(p-c) q h_{1}{ }^{\prime}+h_{1}<0$ and $(p-c-\gamma) q h_{1}{ }^{\prime}+h_{1}<0$ for any $0<\beta<(p-c-\gamma)$.

Case2: If $\varepsilon$ is distributed as normal, then $h_{1}=k e^{-\left(\frac{1}{2 \sigma^{2}}\right) y^{2}}$ and $h_{1}=k e^{-\left(\frac{1}{2 \sigma^{2}}\right) m^{2}}$, where $\mathrm{m}$ and y are as defined above and $k \equiv \frac{1}{\sigma \sqrt{2 \pi}}$. In such a case, $h_{1}{ }^{\prime}=-k((p-c) q-\theta)\left(\frac{1}{\sigma^{2}}\right) e^{-\left(\frac{1}{2 \sigma^{2}}\right) y^{2}}$ and $h_{2}{ }^{\prime}=-k m\left(\frac{1}{\sigma^{2}}\right) e^{-\left(\frac{1}{2 \sigma^{2}}\right) m^{2}} \cdot(p-c) q h_{1}{ }^{\prime}+h_{1}<0$ and $(p-c) q h_{2}{ }^{\prime}+h_{2}<0$, iff $\theta<(p-c-\gamma) q-\frac{1}{(p-c-\gamma) q}$. 